V. V. Mitin, E. A. Ivanova, P. E. Prokhorova, Yu. Yu. Morzherin

$L E B$ «Y-Synthes», Lunacharskogo St., 60, Ekaterinburg, 620027, Russia

\title{
Chlorophenols in organic synthesis
}

This article reviews the alternatives for modifications of $\mathrm{p}$-chlorophenols, $\mathrm{p}$-chloroanisoles with the formation of C-C, C-N, C-S and C-B bonds. It is worth noting the high fundamental as well as practical importance of these reactions due to the availability and cheapness of initial chlorine substituted derivatives of phenol.

Key words: phenol, chlorophenols, biphenyls, reactions combination, the palladiumcatalyzed reaction.

Received: 17.08.2016; accepted: 11.10.2016; published: 01.12.2016.

В. В. Митин, Е. А. Иванова,

П. Е. Прохорова, Ю. Ю. Моржерин

ООО «У-Синтез», 620027, ул. Луначарского, Екатеринбург, Россия

\section{Хлорфенолы в органическом синтезе}

В данном обзоре рассмотрены варианты модификаций п-хлорфенолов и п-хлоранизолов С образованием связей C-C, C-N, C-S и C-B. Стоит отметить высокую не только фундаментальную, но и практическую значимость данных реакций, ввиду доступности и дешевизны исходных хлорзамещенных производных фенола.

Ключевые слова: фенол; хлорфенолы; дифенилы; реакции сочетания; палладий-катализируемые реакции.

Поступило: 17.08.2016; приянято: 11.10.2016; опубликовано: 01.12.2016.

(C) Mitin V. V., Ivanova E. A., Prokhorova P. E., Morzherin Yu. Yu., 2016

\section{Introduction}

Derivatives of p-chlorophenol have a lot of possibilities for further modifications of the chlorine atom with the formation of bonds C-C, C-N, C-S and C-B.

Also these compounds are the most advantageous for use in the industrial synthesis, as they are inexpensive and readily available in large quantities.

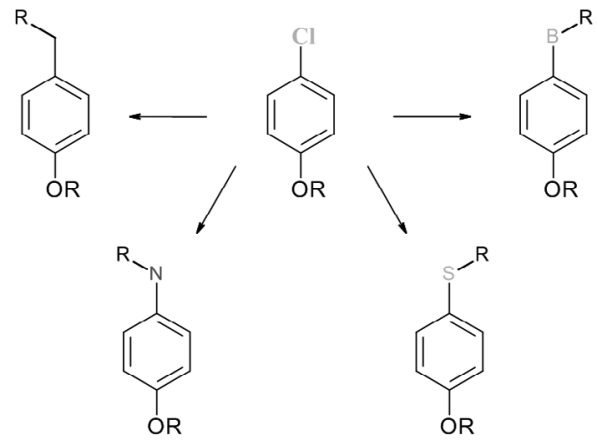




\section{Reactions with the formation of C-C bonds}

\section{The formation of biaryls}

Biaryl fragment is the common structural component of many biologically active compounds [1-2]. Therefore the synthesis of asymmetric biaryl compounds is an important issue.

Palladium-catalyzed reactions of organic boron compounds with arylclorides are one of common synthetic methods for forming new carbon-carbon bonds [3]. Organic boron reagents are readily available, stable to air and non-reactive to various active fragments for which usually the protective groups introduction requires.

The palladium-catalyzed reactions were studied by a group of chinese researchers [4]. MIL-101 was used as ligand.

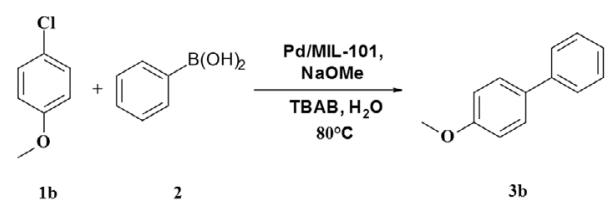

The reaction of $0.5 \mathrm{mmol}$ of 4 -chloroanisole 1a and $0.75 \mathrm{mmol}$ of phenylboronic acid 2 was carried out in nitrogen atmosphere for $20 \mathrm{~h}$. Water solution of $1.5 \mathrm{mmol}$ of base, $0.3 \mathrm{mmol}$ of tetrabutylammoniumbromide (TBAB) was also used. The product 3 was obtaineded with $96 \%$ yield.

Also this research group studied the arylclorides' reaction on the Ullmann mechanism. The same conditions were used, but phenylboronic acid was excluded. It should be noted that in the reaction with 4-chlorophenol $\mathbf{1 b}$ the normal air

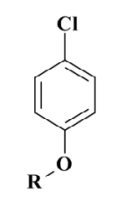

1a $\mathbf{R}=\mathbf{H}$

1b $\mathrm{R}=\mathrm{CH}_{3}$
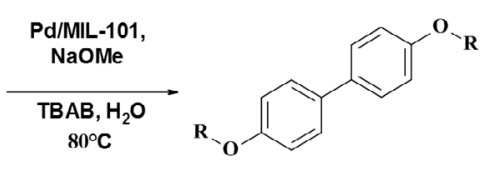

4a $\mathrm{R}=\mathrm{H}$ 4b $\mathrm{R}=\mathrm{CH}_{3}$ was used instead of nitrogen atmosphere. As a result the products $\mathbf{4 a}(96 \%)$ and $\mathbf{4 b}$ (97\%) were formed from compounds 1a and $\mathbf{1} \mathbf{b}$ respectively [4].

Independently of the previous group the interaction of $\mathrm{p}$-chlorophenol derivatives and phenylboronic acid has been studied under the leadership of P. L. Diaconescu [6]. The palladium nanoparticles were used as the catalyst, the interest to it increases because of the benefits offered by these "half-geterogenous catalysts". These advantages combine the characteristics of heterogeneous catalysis (recovery and recirculation) and homogeneous catalysis (relatively low catalyst loading and good selectivity). In addition, because of their large surface area, metal nanoparticles usually have high reactivity under mild conditions [5].

Palladium nanoparticles are prepared by adding palladium (II) salts to the aqueous dispersion of polyaniline (PANI). High surface area and porosity of PANInanofibers are the ideal environment to make nanocomposites metal/polyaniline. In order to take advantage of these characteristics, PANI-nanofibers were employed as the carriers of palladium nanoparticles. The products $\mathbf{3 a}(88 \%)$ and $\mathbf{3 b}$ (92\%) were formed as a result of this catalyst using [6].

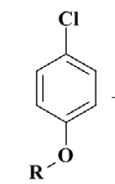

1a $\mathrm{R}=\mathrm{H}$
1b $\mathrm{R}=\mathrm{CH}_{3}$

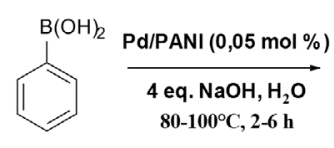

2

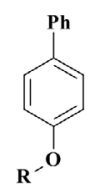

3a $\mathbf{R}=\mathbf{H}$ 3b $\mathbf{R}=\mathbf{C H}_{3}$
Another method of p-phenylphenol synthesis was proposed by N. A. Bumagin and V. V. Bykov [7]. They described the large number of biaryl compounds which 
were obtained, in particular from chlorophenol 1a with $92 \%$ yield.<smiles>Oc1ccc(Cl)cc1</smiles>

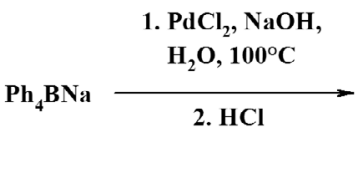

1a
5

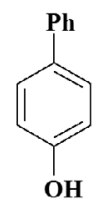

$3 a$
$3 \mathrm{Mol} \%$ of palladium catalyst, $4 \mathrm{mmol}$ of the base and $1 \mathrm{mmol}$ of borate 4 were used. The reaction was carried out during three hours. This method is not inferior to the efficiency of both the preceding and the following methods.

The synthesis, including the use of simple and easily available catalytic system of cobalt and titanium, looks attractive because it takes place under mild conditions and has high selectivity and regioselectivity. The cobalt/titanium complex, which catalyzes the cross-coupling reactions between aryl derivatives of magnesium and arylchlorides, was presented by X. F. Duan and his team [8]. This reaction easily proceeds in the presence of $40 \mathrm{~mol} \% \mathrm{Ti}(\mathrm{OEt})_{4}$ and $7.5 \mathrm{~mol} \%$ of $\mathrm{CoCl}_{2}, 15 \mathrm{~mol} \% \mathrm{PBu}_{3}$.

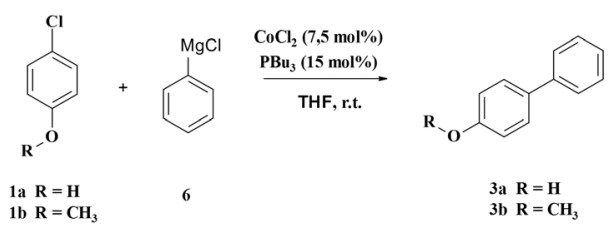

The compounds $\mathbf{3} \mathbf{a}$ and $\mathbf{3} \mathbf{b}$ are formed with the yield $56 \%$ and $86 \%$, respectively. The reactions involving organometallic reagents are very effective and practical way for the formation of the $\mathrm{C}-\mathrm{C}$ bonds. And another group of researchers worked with Grignard reagent [9]. The products $\mathbf{3} \mathbf{a}$ and $\mathbf{3 b}$ are formed with the yeild $95 \%$ and $97 \%$ when same starting materials 1a and $\mathbf{1 b}$ and reagents $\mathrm{Pd}_{2}(\mathrm{dba})_{3}(1 \mathrm{~mol} \%)$,
IPrHCl (4 mol \%) and phenyl magnesium bromide 6 (2.5 and 1 equivalent respectively) in tetrahydrofuran at temperature of $80{ }^{\circ} \mathrm{C}$ [9].

M.-J. Jin and colleagues [10] also worked on getting of biaryl derivatives. They used complex of palladium and diketoiminophosphine as the catalyst. The results show that this catalytic system allows the use of less reactive substrates such as deactivated or sterically hindered arylchlorides. The $0.5 \mathrm{~mol} \%$ catalyst was enough to achieve high efficiency under relatively mild reaction conditions.

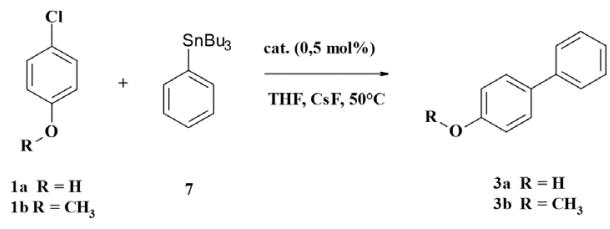

The products $\mathbf{3} \mathbf{a}$ and $\mathbf{3} \mathbf{b}$ are formed with a $89 \%$ yield in carrying out these reactions for 4 and 5 hours respectively.

The group of researchers under the supervision of A. Albini [11] proposed to substitute the chlorine to durene $\mathbf{8}$ with $60 \%$ yield of reaction product 9 .

The photoarylation was performed using $0.2 \mathrm{~mol}$ of durene 8 and $0.02 \mathrm{~mol}$ of 4-chlorophenol 1a in $30 \mathrm{ml}$ of solvent for 7 hours.

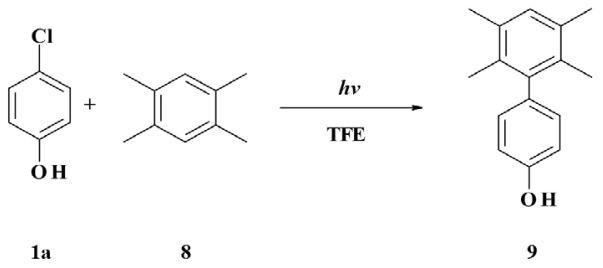

Thus, the synthesis of biaryl compounds is quite popular reactions of cross-coupling of chlorophenols with the participation of the various catalitic systems. The most profitable for the getting of biaryls is the using of reactions involv- 
ing boronic acid and palladium nanoparticles and tin organic reactions.

Introduction of other functional groups

Arylnitriles, which are included in the structure of dyes, herbicides, natural products and pharmaceuticals, are the following direction of the modifications. They are also useful intermediate products for the synthesis [12-13]. The reactions for obtaining aromatic nitriles were conducted by N. E. Leadbeater with a colleague [14]. The process was carried out in the microwave reactor with installed power of $120 \mathrm{w}$ and the threshold pressure of 200 pounds per square inch.
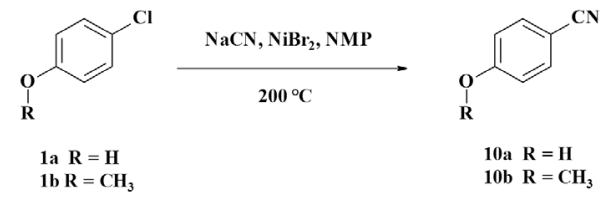

In the experiments there were used 1 mmole of arylchloride, $2 \mathrm{mmol}$ of sodium cyanide, $1 \mathrm{mmol}$ of nickel bromide in $1 \mathrm{ml}$ of N-methyl-2-pyrrolidone (NMP). As a result after 20 and 10 minutes respectively the products 10a (99\%) and 10b (61\%) were formed [14].

Thus, this reaction is very useful to make p-cyanophenols, because using of 4-chlorophenol leads to the selective and high yield synthesis.

The reactions of p-chlorophenol derivatives with aldehydes make it easy to obtain alkylarylketones with good yields. They are widely used in pharmaceutical and perfume industry, dye and agricultural chemistry. These compounds are synthesized usually under using reactions on the Friedel-Crafts mechanism. The reactions include dangerous reagents and does not work with the use of arenes con- taining electron-withdrawing substituents [15-17].

The group of researchers under the supervision of J. Xiao [18] was offered more convenient method of synthesis. They carried out the reactions in the presence of palladium catalysts using different ligands, which showed high activity in relation to chlorophenols and chloroanisoles. It has been shown that the use of ligand $\mathbf{L} 1$ gives the highest yields.

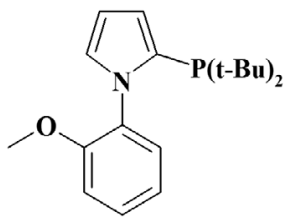

L1

The use of dimethylamine as a solvent, the presence of molecular sieves $4 \AA$ and pyrrolidine in the reaction mixture when heated to $140{ }^{\circ} \mathrm{C}$ also has a positive effect on selectivity and yield of the reaction.

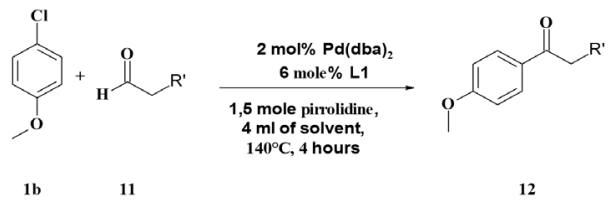

In the result they received the large number of compounds $\mathbf{1 2}$ with different substituents R' (40-78 \% yields), the nature of which does not affect to the product.

a-Arylcarbonyl derivatives are the important structural compounds in many natural products and pharmaceutically active substances. Although arylation of simple monocarbonyl compounds is the well-known technique, the metal-catalyzed arylation of $\beta$-dicarbonyl derivatives is the more difficult task. Sterically demanding ligand - di-tret-butylneopentylphosphin (DtBP) - in combination with $\mathrm{Pd}(\mathrm{dba})_{2}$ is an effective catalyst for the combination of arylchlorides 
with diethylmalonate 13 . As a result of experiments the compounds 14a (85\%) and $\mathbf{1 4 b}(83 \%)$ were obtained [19].

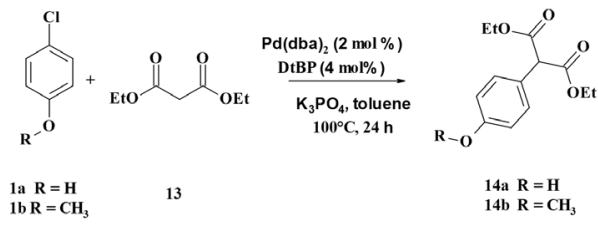

The cross-coupling reaction on the Sonogashira mechanism between arylhalides and terminal alkyne has become one of the most widely applicable reactions which used for the formation of carboncarbon bonds in organic chemistry. The reaction has been proposed as effective method for the synthesis of dendrimers, conjugated oligomers and polymers, substituted alkynes. They are also intermediates in the synthesis of natural products, pharmaceuticals, optical materials and other [20-24].

The group of researchers under the supervision of S. Pal [25] was investigated the cross-coupling reactions of phenylacetylene and various arylhalogenides using the synthesized palladium - ligand complex L2 as a catalyst.

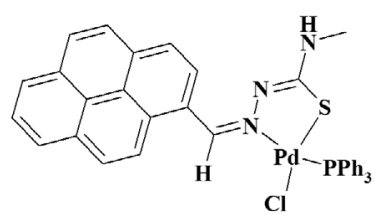

L2

The reactions were carried out in DMF in the presence of triethylamine at room temperature for 24 hours. The results were compounds 15a (50\%) and $\mathbf{1 5 b}$ (54\%) [25].

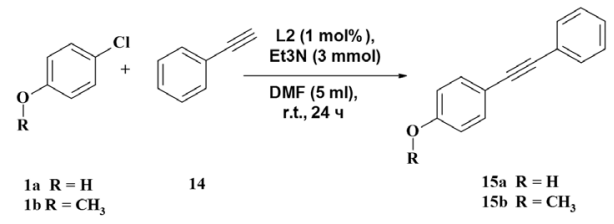

The arylhalogenides were also used for the formation of indazoles. Indazoles are rare in nature, but they are the important class of heterocycles for pharmaceutical and agrochemical industries. In addition, the synthesis of 3 -aryl-1H-indazoles by cross-combination of $1 \mathrm{H}$-indazoles, having a methyl substituent in position 3 , and arylhalogenides is attractive, because it allows to use the resulting compound in further modifications.

B. A. Egan and M. P. Burton [26] synthesized these compounds. The starting substances were derivatives of arylhalogenides (1 equiv.) and borated indazole ( 1,3 eqiv.) obtained by the same researchers. The complex with palladium $\mathbf{L} 3$ was used as the catalyst.<smiles>[H][Y8]([H])(OC)c1ccccc1-c1ccccc1</smiles><smiles>CC(C)c1cc(C(C)C)c(-c2ccccc2C(C)C)c(C(C)C)c1</smiles>

L3

These reactions took place at $55^{\circ} \mathrm{C}$ for $16 \mathrm{~h}$ (conditions $\mathrm{A}$ ) and under the microwave radiation $\left(100^{\circ} \mathrm{C}\right.$ for $20 \mathrm{~min}$ (conditions B)). The mixture of tert-butylmethyl ether (TBME) and water in a ratio of 10:1 was used as a solvent.
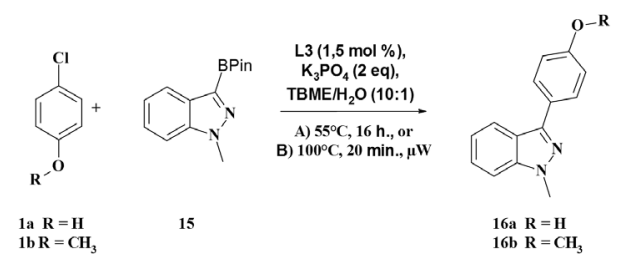

The results were synthesized compounds $16 \mathbf{a}$ and $\mathbf{1 6 b}$ with a yield of $84 \%$ and $76 \%$, respectively [26].

In addition the reactions with other derivatives of indazole were investigated 
under the same conditions and the corresponding products were obtained. The results are presented in Table 1.

A fragment of the $\gamma$-lactone is presented in many biologically active natural compounds. In particular some of the benzyl - and arylsubstituted $\gamma$-lactones exhibit anticancer activity or are used as intermediates for the synthesis of antitumor antibiotic agents [27-29].

The group of researchers under the suoervision of A. Albini [30] studied photochemical reactions of arylchloride derivatives and acids $\mathbf{K} \mathbf{1}, \mathbf{K} \mathbf{2}$ and $\mathbf{K} 3$.

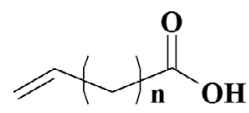

$$
\begin{aligned}
& K 1, n=1 \\
& K 2, n=2 \\
& K 3, n=3
\end{aligned}
$$

Since the use of polar (proton) solvents favors the photolysis, irradiation (310 nm, $254 \mathrm{~nm}$ for p-butoxybenzene) was carried out in the system acetonitrilewater in the ratio 5:1.

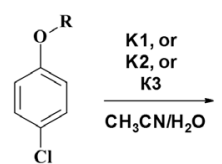

1a $\mathbf{R}=\mathbf{H}$

1b $\mathrm{R}=\mathrm{CH}_{3}$ 1c $\mathrm{R}=\mathrm{C}_{4} \mathrm{H}_{9}$

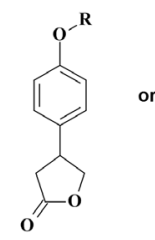

23a $\mathbf{R}=\mathbf{H}$ 23b $\mathrm{R}=\mathrm{CH}_{3}$ 23c $\mathbf{R}=\mathrm{C}_{4} \mathrm{H}_{9}$

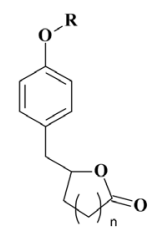

24a $R=H, n=2$ 24b $\mathrm{R}=\mathrm{CH}_{3}, \mathrm{n}=2$ 24c $\mathrm{R}=\mathrm{C}_{4} \mathrm{H}_{9}, \mathrm{n}=2$ $25 \mathrm{R}=\mathrm{C}_{4} \mathrm{H}_{9}, \mathrm{n}=3$
The results of the reactions are presented in the Table 2.

The reactions of chlorophenol with other unsaturated acids were also examined. The results of the reactions are presented in the Table 3 [30].

Table 1

Arylation of indazole derivatives

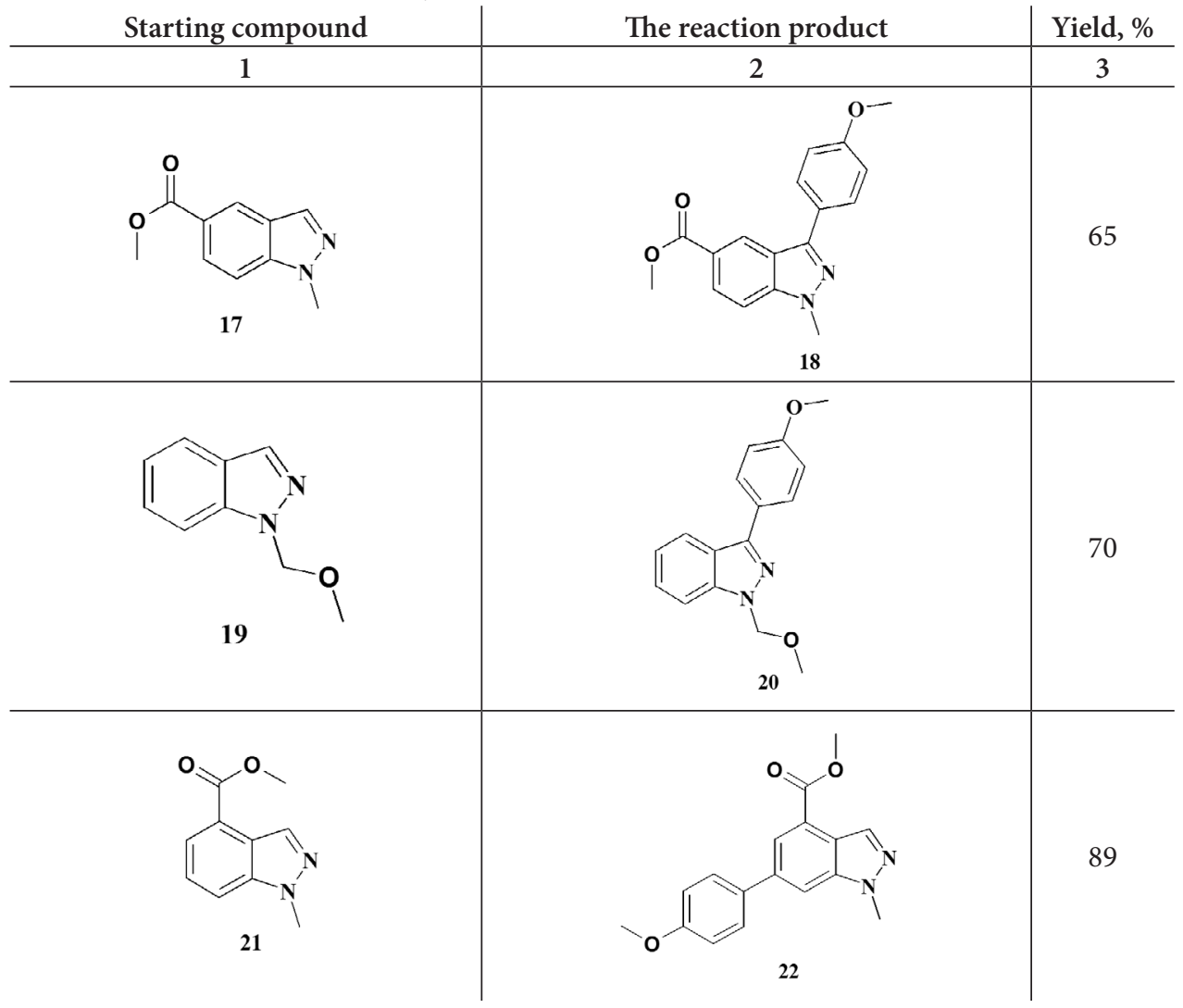


The cross-coupling with formation of $\mathrm{C}-\mathrm{C}$ bond is large area of the chlorophenols use. The products of synthesis are used in many areas, in particular as biologically active substances.

Table 2

Photoinduced synthesis of lactones

\begin{tabular}{c|c|c|c} 
Substituent R & Time, $\mathbf{h}$ & Product & Yield, \% \\
\hline $\mathrm{H}$ & 14 & 23a-c & 52 \\
\hline $\mathrm{H}$ & 14 & 24a & 95 \\
\hline $\mathrm{CH}_{3}$ & 14 & 24b & 72 \\
\hline $\mathrm{C}_{4} \mathrm{H}_{9}$ & 8 & 24c & 57 \\
\hline $\mathrm{C}_{4} \mathrm{H}_{9}$ & 14 & $\mathbf{2 5}$ & $\begin{array}{c}57 \\
\text { Table 3 }\end{array}$
\end{tabular}

Photoinduced synthesis of lactones from chlorophenol

\begin{tabular}{|c|c|c|c|}
\hline Acid & Time, $\mathbf{h}$ & Product & Yield, \% \\
\hline 1 & 2 & 3 & 4 \\
\hline$E \mathbf{E}$ & 24 & & 54 \\
\hline Et & 24 & 26 & 67 \\
\hline $\mathrm{K}^{\mathrm{HO}}$ & 36 & 27 & $\begin{array}{c}61, \\
\text { phenol } \\
(6 \%) \\
\text { as by- } \\
\text { product }\end{array}$ \\
\hline
\end{tabular}

\section{Reactions with formation of $\mathrm{C}-\mathrm{N}$ bond}

The cross-coupling reactions of chlorophenols include not only the $\mathrm{C}-\mathrm{C}$ bond formation, but $\mathrm{C}-\mathrm{N}$ bond formation as well. Moreover nitrogencontaining organic compounds possess diverse biological activity, but also they could be a building blocks for various macromolecules and new materials [31-34].

The group of indian researchers have studied reactions with participation of the copper based catalyst. The reaction was carried out using $1 \mathrm{mmol}$ of arene, 1.1 mmol of amine, $1.5 \mathrm{mmol}$ of base in $2 \mathrm{ml}$ of solvent under nitrogen atmosphere.

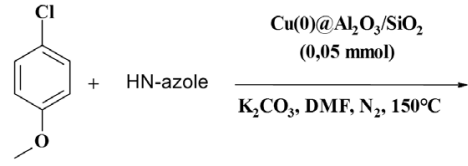

1a $\mathbf{R}=\mathbf{H}$ 1b $\mathrm{R}=\mathrm{CH}_{3}$

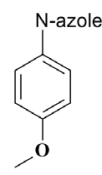

30-32

The results of the reactions are shown in the Table 4 [35].

American researchers also studied the substitution of chlorine in arylchlorides to nitrogen-containing compounds, however instead of the copper catalyst they used the palladium complex with ligand L4. 
Table 4

$\mathrm{N}$-arylation of heterocyclic amines by arylhalides

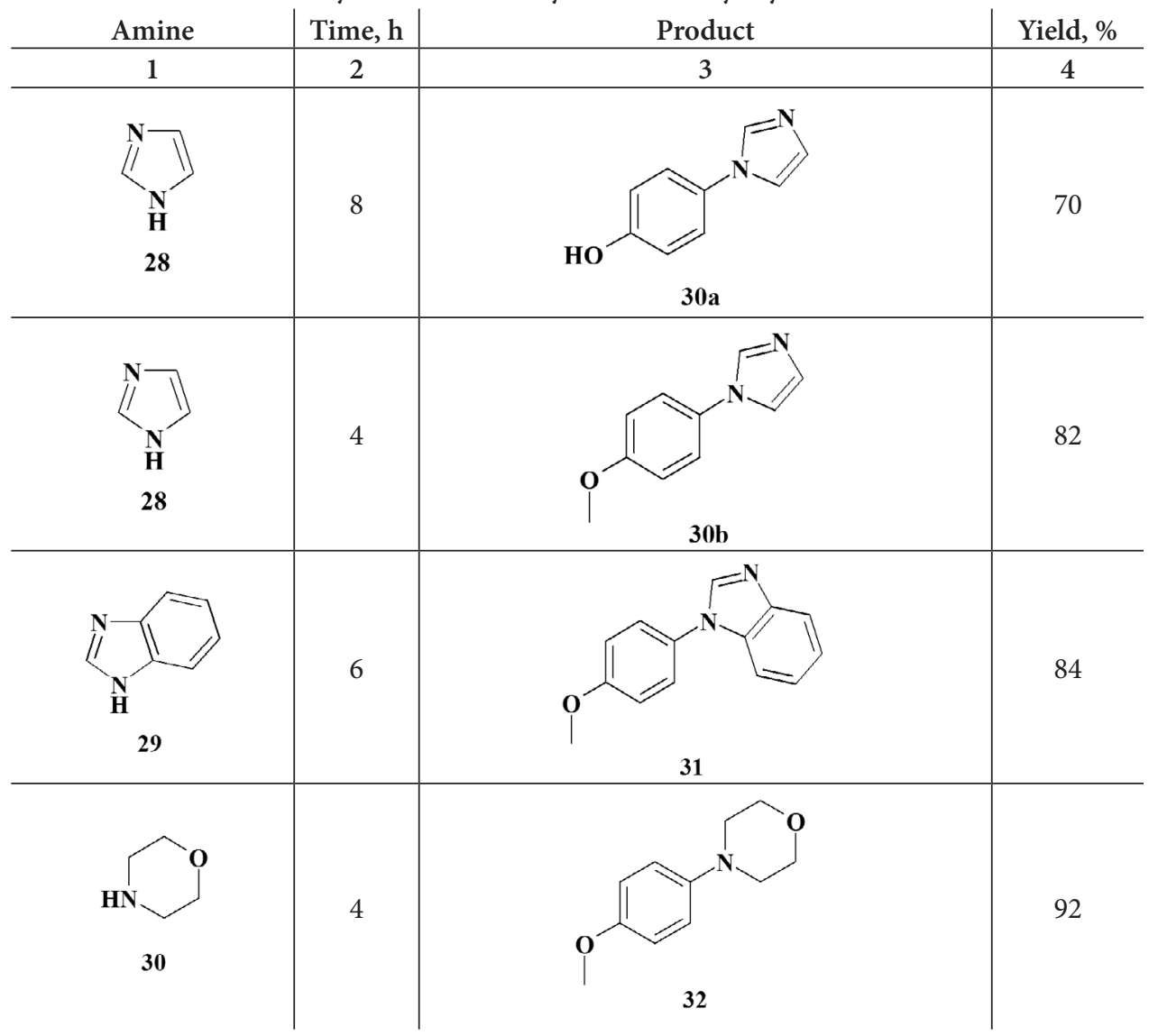

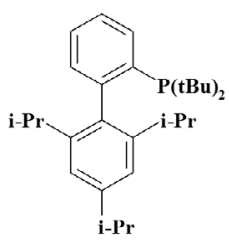

L4

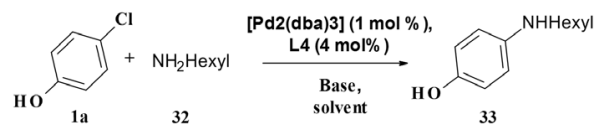

They investigated the influence of solvent, base and temperature and obtained following results (Table. 5) [36].

It was noted that conditions 3 using LiN(TMS) ${ }_{2}$ in toluene at $50^{\circ} \mathrm{C}$ for 2 hours are the best to produce compound 33 . The yield of the target product was $94 \%$.
$\mathrm{N}$-arylation by chlorophenol

\begin{tabular}{|c|c|c|c|c|c|}
\hline № & $\begin{array}{l}\mathscr{\mathscr { D }} \\
\tilde{\Xi}\end{array}$ & 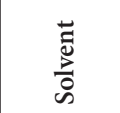 & 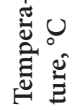 & : & 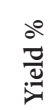 \\
\hline 1 & $\operatorname{LiN}(\mathrm{TMS})_{2}$ & TGF & r.t. & 46 & 94 \\
\hline 2 & $\operatorname{LiN}(\mathrm{TMS})_{2}$ & TGF & 40 & 24 & 94 \\
\hline 3 & $\mathrm{LiN}(\mathrm{TMS})_{2}$ & Toluene & 50 & 2 & 94 \\
\hline 4 & $\mathrm{NaO} t \mathrm{Bu}$ & Toluene & 100 & 24 & 89 \\
\hline
\end{tabular}

The reactions with participation of aminoheterocycle 34 were also carried out. One from obtained compounds was the product 35 in $92 \%$ yield.

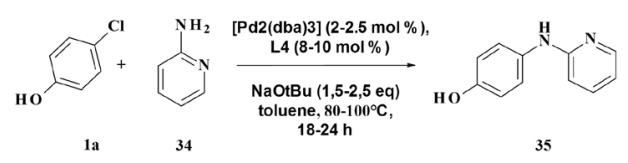


These reactions are the important part of cross-coupling series with the formation of $\mathrm{C}-\mathrm{N}$ bond.

The group of american researchers also used the palladium catalyst. The compound L5 was used as ligand.

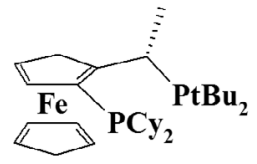

L5

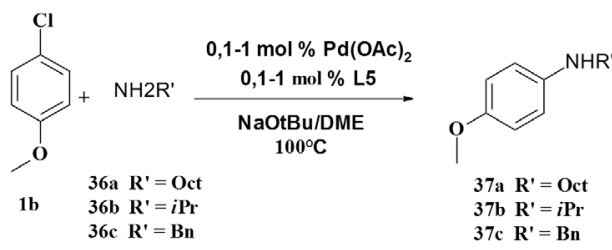

The reaction results are given in the Table 6.

The reactions were carried out with 1:1 ratio of palladium acetate to ligand L5. $1.0 \mathrm{Mmol}$ of chloranisole $\mathbf{1 b}$ and 1.2 equiv. of amine, 1.4 equiv of $\mathrm{NaO} t \mathrm{Bu}$ in $1 \mathrm{ml}$ of DME were used. In the case octylamine 36a 3.0 equiv. of this substance was required. All the reactions proceed with good yields.

Reactions with chlorophenol 1a were also studied and corresponding phenylamines 39a-b were obtained.

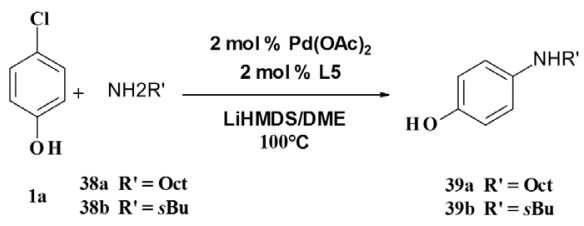

The results of the studies listed in the Table 7.

The reaction was performed under same conditions [37].

Thus, the reaction using chloroanisole has better yields in comparison with aniliration of chlorophenol and requires smaller amount of reagents.

In addition to amination of chlorophenols and anisoles there are also the reactions of amidation. The group of researchers under the supervision of S. L. Buchwald [36] studied these reactions. First, the effect of different conditions to the amidation of chloroanisoles $\mathbf{1 b}$ with benzamide $\mathbf{4 0}$ was studied. Palladium catalyst and ligand $\mathrm{L} \mathbf{4}$ were used.

The reaction was carried out with the use of 1.2 equiv of amide 40, $0.5 \mathrm{~mol} \%$ catalyst, $2.5 \mathrm{~mol} \%$ ligand in 0.5 moles of solvent.

The results are shown in the Table 8.

It was noted that the highest yields are produced in conditions $\mathbf{1}$ and $\mathbf{5}$.

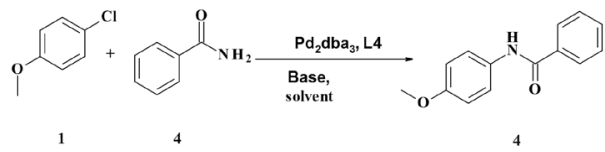

Then, the series of compounds were obtained (Table 9).

1.0-1.5 Equiv. of amide, 1.2-1.5 equiv of base, $0.5 \mathrm{~mol}$ of solvent and the ratio kat/ligand $=1 / 2,5$ were used.

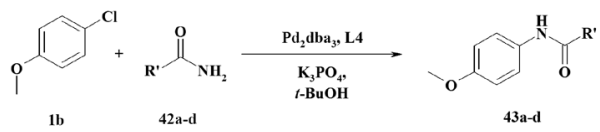

The high yields were observed with low amounts of reagents, except the reaction with carboxamide [38].

Thus, the substitution of chlorine with the formation of $\mathrm{C}-\mathrm{N}$ bond plays as important role in modifying of chloroarenes as the cross-coupling with the formation of $\mathrm{C}-\mathrm{C}$ bond. 
$\mathrm{N}$-arylation by chloroanisole

Table 6

\begin{tabular}{c|c|c|c|c|c|c} 
№ & Reagent & Catalyst, $\mathbf{m o l} \%$ & Temperature, ${ }^{\circ} \mathrm{C}$ & Time, $\mathbf{h}$ & Product & Yield, $\%$ \\
\hline 1 & $36 \mathrm{a}$ & 0,1 & 100 & 48 & $37 \mathbf{a}$ & 92 \\
\hline 2 & $36 \mathrm{~b}$ & 1,0 & 100 & $18-24$ & $37 \mathbf{b}$ & 94 \\
\hline 3 & $36 \mathrm{c}$ & 0,1 & 100 & 48 & $37 \mathrm{c}$ & 90
\end{tabular}

\section{Reactions with formation of C-S bond}

Arylsulphides are valuable intermediate products in the synthesis of biologically and pharmaceutically active molecules, organic materials or intermediates in the production of these molecules. The number of arylsulphides showed potential clinical application, for example, for the treatment of Alzheimer's disease and Parkinson's disease, for the treatment of asthma and obstructive lung diseases, for the treatment of human immunodeficiency virus (HIV) [39-44].

The group of american researchers under the leadership of J. F. Hartwig [37] studied the interaction of chloroarenes and thiol derivatives.

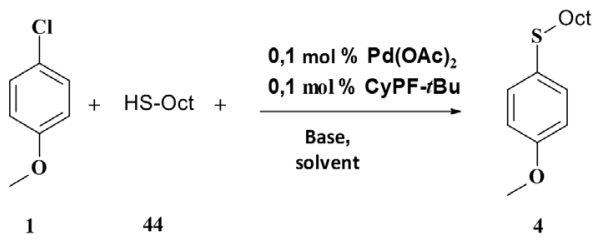

The results of researches are shown in the Table 10.

All experiments were performed with a1:1 ratio of metal to ligand, with $1 \mathrm{mmol}$ of both 4-chloroanisole $\mathbf{1 b}$ and 1-octanethiol 44 and 1.1 equiv. of base in $1.5 \mathrm{ml}$ solvent. The compound L5 was selected as a ligand. In conditions $70,05 \mathrm{~mol} \%$ of catalyst was used. In terms of $\mathbf{8}\left[\mathrm{Pd}(\mathrm{dba})_{2}\right]$ was used as precursor of palladium acetate.

It was noted that conditions under number $\mathbf{4}$ are the best.
Also, the number of reactions with 4-chloroanisole and thiophenol were carried out.

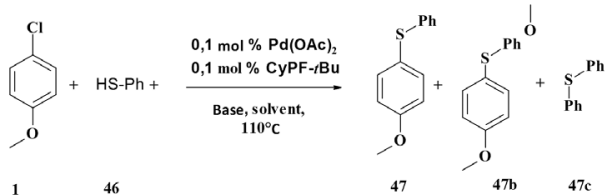

In these conditions the reaction was not selective with the formation of byproducts $47 \mathrm{~b}$ and $47 \mathrm{c}$. As a result of the Table 7

Amination of chlorophenol

\begin{tabular}{c|c|c|c|c} 
№ & Reagent & Time, $\mathbf{h}$ & Product & Yield, \% \\
\hline 1 & $38 \mathrm{a}$ & 18 & 39a & 72 \\
\hline 2 & $38 \mathrm{~b}$ & 20 & 39b & 66
\end{tabular}

Table 8

Amidation by benzamide

\begin{tabular}{c|l|l|c} 
№ & \multicolumn{1}{|c|}{ Base } & \multicolumn{1}{c}{ Solvent } & Yield, \% \\
\hline 1 & $\mathrm{~K}_{3} \mathrm{PO}_{4}$ & $t$ - $\mathrm{BuOH}$ & 94 \\
\hline 2 & $\mathrm{~K}_{3} \mathrm{PO}_{4}$ & Toluene & 89 \\
\hline 3 & $\mathrm{~K}_{3} \mathrm{PO}_{4}$ & 1,4 - dioxane & 79 \\
\hline 4 & $\mathrm{~K}_{3} \mathrm{CO}_{3}$ & $t$ - $\mathrm{BuOH}$ & 45 \\
\hline 5 & $\mathrm{Cs}_{2} \mathrm{CO}_{3}$ & $t$ - $\mathrm{BuOH}$ & 97 \\
\hline 6 & $t$-BuONa & $t$ - $\mathrm{BuOH}$ & 28 \\
\hline 7 & LHMDS & Toluene & 1
\end{tabular}

Table 9

\begin{tabular}{|c|c|c|c|c|c|}
\hline \multicolumn{6}{|c|}{ Amidation of chloroanisoles } \\
\hline$\stackrel{10}{2}$ & 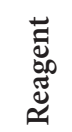 & ๘ี & ¿ & 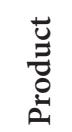 & $\frac{d}{0}$ \\
\hline 1 & $42 a$ & $\mathrm{Me}$ & 1 & $43 a$ & 99 \\
\hline 2 & $42 b$ & $\mathrm{Cy}$ & 1 & $43 \mathrm{~b}$ & 96 \\
\hline 3 & $42 c$ & $\mathrm{H}$ & 4 & $43 c$ & 82 \\
\hline 4 & $42 d$ & $o$-phenyl & 2 & $43 d$ & 92 \\
\hline
\end{tabular}


optimizations, conditions for selective synthesis were found (Table. 11).

All experiments were performed with a 1:1 ratio of catalyst to ligand, $1 \mathrm{mmol}$ of both starting compounds $\mathbf{1 b}$ and 46 and 1.1 equiv of base at $110^{\circ} \mathrm{C}$ in $1.5 \mathrm{ml}$ of solvent. It was noted that it is cheaper to use conditions under the number $\mathbf{1 1}$.

The following reactions were held in these conditions and the corresponding products were obtained (Table 12).

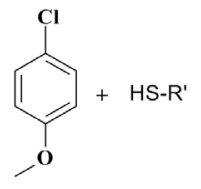

$148 \mathrm{a}-\mathrm{c}$

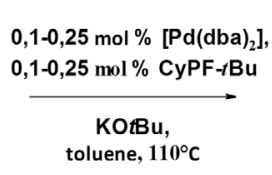

toluene, $110^{\circ} \mathrm{C}$

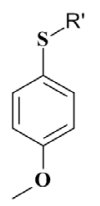

$49 a-$
All experiments were performed with a 1:1 ratio of catalyst to ligand, $1 \mathrm{mmol}$ of

both starting compounds $\mathbf{1 b}$ and $\mathbf{4 8 a} \mathbf{a}-\mathbf{c}$ in toluene $(1.5 \mathrm{ml})$ for $2-24 \mathrm{~h}$ at $110^{\circ} \mathrm{C}$.

The reactions were also carried out with 4-chlorophenol and the corresponding products are obtained (Table 13).<smiles>Oc1ccc(Cl)cc1</smiles>

1 48e-d

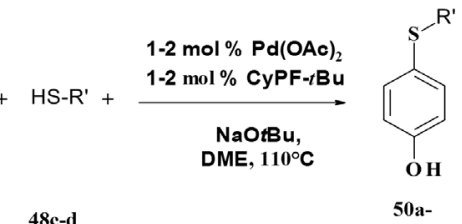

All experiments were performed with a 1:1 ratio of catalyst to ligand, $1 \mathrm{mmol}$ of both starting compounds in DME $(1.5 \mathrm{ml})$ for $2-5 \mathrm{~h}$ under the heating at $110^{\circ} \mathrm{C}$ [45-46].

Thus, the cross-coupling with the formation of C-S bonds are the important reactions of the chlorine atom substitution.

Table 10

The interaction of chloroanisole and 1-octanethiol

\begin{tabular}{c|c|c|c|c|c} 
№ & Base & Solvent & Temperature, ${ }^{\circ} \mathbf{C}$ & Time, $\mathbf{h}$ & Yield, $\%$ \\
\hline 1 & $\mathrm{NaO}$ tBu & DME & 100 & 18 & 84 \\
\hline 2 & $\mathrm{KO}$ tBu & DME & 100 & 18 & 80 \\
\hline 3 & $\mathrm{NaHMDS}$ & $\mathrm{DME}$ & 100 & 18 & 57 \\
\hline 4 & $\mathrm{NaOtBu}$ & $\mathrm{DME}$ & 110 & $<4$ & 98 \\
\hline 5 & $\mathrm{KO} t \mathrm{Bu}$ & $\mathrm{DME}$ & 110 & 18 & 87 \\
\hline 6 & $\mathrm{NaOtBu}$ & 1,4 -dioxane & 110 & 5 & 94 \\
\hline 7 & $\mathrm{NaOtBu}$ & $\mathrm{DME}$ & 110 & 48 & 85 \\
\hline 8 & $\mathrm{NaOtBu}$ & $\mathrm{DME}$ & 110 & 7 & 96
\end{tabular}

The interaction of chloroanisole and 1-thiophenol

\begin{tabular}{c|c|c|c|c|c|c} 
№ & Base & Solvent & Catalyst & Loading, $\%$ & Time, $\mathbf{h}$ & 47:47b:47c, $\%$ \\
\hline 1 & $\mathrm{NaO} t \mathrm{Bu}$ & DME & $\mathrm{Pd}(\mathrm{OAc})_{2}$ & 0,5 & 12 & $91: 4: 5$ \\
\hline 2 & $\mathrm{KO} t \mathrm{Bu}$ & $\mathrm{DME}$ & $\mathrm{Pd}(\mathrm{OAc})_{2}$ & 0,5 & 12 & $98: 1: 1$ \\
\hline 3 & $\mathrm{NaHMDS}$ & $\mathrm{DME}$ & $\mathrm{Pd}(\mathrm{OAc})_{2}$ & 0,5 & 12 & $71: 15: 14$ \\
\hline 4 & $\mathrm{LiHMDS}$ & DME & $\mathrm{Pd}(\mathrm{OAc})_{2}$ & 0,5 & 12 & $56: 24: 20$ \\
\hline 5 & $\mathrm{NaOtBu}$ & 1,4 - dioxane & $\mathrm{Pd}(\mathrm{OAc})_{2}$ & 0,5 & 12 & $96: 2: 2$ \\
\hline 6 & $\mathrm{KO} t \mathrm{Bu}$ & 1,4 - dioxane & $\mathrm{Pd}(\mathrm{OAc})_{2}$ & 0,5 & 12 & $97: 2: 1$ \\
\hline 7 & $\mathrm{NaOtBu}$ & Toluene & $\mathrm{Pd}(\mathrm{OAc})_{2}$ & 0,5 & 12 & $98: 1: 1$ \\
\hline 8 & $\mathrm{KO} t \mathrm{Bu}$ & Toluene & $\mathrm{Pd}(\mathrm{OAc})_{2}$ & 0,5 & 12 & $>98: 1:<1$ \\
\hline 9 & $\mathrm{KO} t \mathrm{Bu}$ & Toluene & $\mathrm{Pd}(\mathrm{OAc})_{2}$ & 1,0 & 6 & $>98:<1:<1$ \\
\hline 10 & $\mathrm{KO} t \mathrm{Bu}$ & Toluene & {$\left[\mathrm{Pd}(\mathrm{dba})_{2}\right]$} & 0,5 & 12 & $>99,5: 0,5:-$ \\
\hline 11 & $\mathrm{KO} t \mathrm{Bu}$ & Toluene & {$\left[\mathrm{Pd}(\mathrm{dba})_{2}\right]$} & 1,0 & $<4$ & $>99,5: 0,5:-$
\end{tabular}


Table 12

Thioarylation of 4-chloroanisole

\begin{tabular}{l|l|l|l|l} 
Catalyst, $\mathbf{m o l} \%$ & Reagent & Product & Yield, \% \\
\hline 0,1 & $48 \mathrm{a}$ & & \\
\hline & & &
\end{tabular}

Table 13

Thioarylation of 4-chlorophenol

\begin{tabular}{|c|c|c|c|c|}
\hline Catalyst, mol\% & Reagent & $\mathrm{R}^{\prime}$ & Product & Yield, \% \\
\hline 2,0 & $48 \mathrm{c}$ & & $50 \mathrm{a}$ & 91 \\
\hline 1,0 & $48 \mathrm{~d}$ & & $50 \mathrm{~b}$ & 91 \\
\hline
\end{tabular}

\section{Reactions with formation of C-B bond}

Arylboronic acids are the universal reagents for organic synthesis which used in the formation of $\mathrm{C}-\mathrm{O}, \mathrm{C}-\mathrm{N}$ and $\mathrm{C}-\mathrm{C}$ bonds [47]. In addition, the use of organoboranes is particularly attractive because of their high stability and low toxicity.

S. L. Buchwald and his team [48] have conducted researches in this area. They carried out the cross-coupling of 4-chlorophenol 1a or 4-chloroanisole $\mathbf{1 b}$ and bis(pinacolato)diboron 51.

The ratio of catalyst and ligand was 1:2. Using $2 \mathrm{~mol} \%$ of palladium acetate the re-

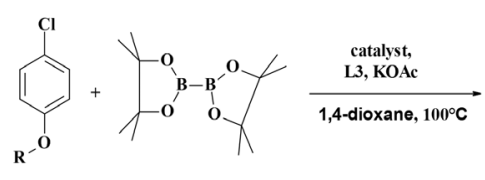

1a $\mathbf{R}=\mathbf{H}$ $1 \mathrm{~b} \mathrm{R}=\mathrm{CH}_{3}$

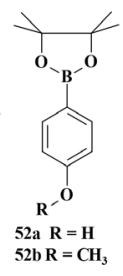

the formation of $97 \%$ of the product $\mathbf{5 2 b}$. In the case of $0.05 \mathrm{~mol}_{2} \mathrm{Pd}_{2} \mathrm{dba}_{3}$ using the product 52b with $94 \%$ yield was formed within $24 \mathrm{~h}$ and while increasing the amount of catalyst to $1 \mathrm{~mol} \%$ the product 52b was formed in $10 \mathrm{~min}$. with $97 \%$ action was performed for 10 minutes with 
yield and 52a was formed in 30 minutes with $82 \%$ yield.

The reaction with chloroanisole also was carried out in the presence of 2.0 mol\% of palladium acetate, ligand L5 (in relation to the catalyst $3: 1$ ), potassium phosphate ( 3 equixv.) in $2 \mathrm{ml}$ of solvent at room temperature. The result is the product with a $97 \%$ yield [48].

Thus, the cross-couplings with the formation of $\mathrm{C}-\mathrm{B}$ bonds are no less important than the previous reactions.

\section{Conclusion}

Thus, in this review the high synthetic potential of the p-chlorophenols, p-chloroanisole was described. It is shown that due to the formation of new bonds $\mathrm{C}-\mathrm{C}$, C-N, C-S and C-B instead of C-Cl the derivatives of chlorophenol found wide application in the synthesis of complex or- ganic compounds. It is worth noting that there is the high not only fundamental but also practical importance of these reactions, due to the availability and cheapness of initial chlorine substituted derivatives of phenol.

\section{In Russian}

\section{Введение}

Производные $n$-хлорфенола имеют множество возможностей для дальнейших модификаций атома хлора с образованием связей C-C, C-N, C-S и С-B.

Также эти соединения являются наиболее выгодными для применения в промышленном синтезе, так как они стоят недорого и легкодоступны в

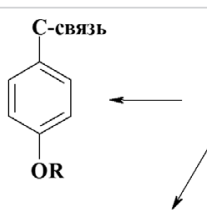

OR
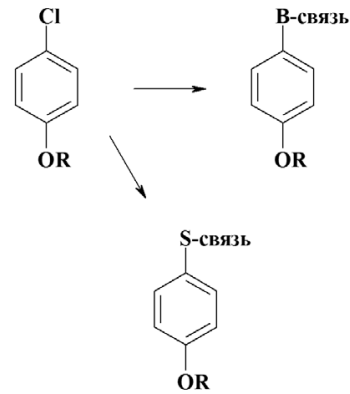
больших количествах.

\section{Реакции с образованием С-С связи}

\section{Образование биарилов}

Биарильный фрагмент является общим структурным компонентом многих биологически активных соединений [1-2]. Следовательно, синтез несимметричных или замещенных несколькими алкильными фрагментами биарильных соединений является актуальной проблемой.

Катализируемые палладием реакции борорганических соединений с арилхлоридами являются одним из универсальных синтетических мето- дов формирования новой углеродуглеродной связи [3]. Борорганические реагенты легко доступны, стабильны на воздухе и инертны по отношению к различным функциональным группам, для которых требуется введение защитной группы и затем ее дальнейшее снятие.

Так, реакции с использованием палладиевого катализатора были изучены группой китайских исследователей. В качестве лигандов использовалось 
соединение MIL-101, структура которого не раскрывалась.

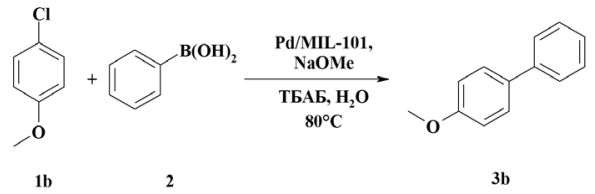

Реакцию 0,5 ммоль 4-хлоранизола 1а и 0,75 ммоль фенилбороновой кислоты 2 проводили в атмосфере азота в течение 20 ч. Использовалось 1,5 ммоль основания, 0,3 ммоль тетрабутиламмонийбромида (ТБАБ) в 4 мл воды. В результате образовался продукт 3 с выходом $96 \%$.

Также этой группой исследователей были изучены реакции арилхлоридов друг с другом по механизму Ульмана. Использовались те же условия, однако исключена фенилбороновая кислота. Кроме того, в реакции с 4-хлорфенолом $\mathbf{1 b}$ вместо атмосферы азота использовался обычный воздух. В результате из соединений $\mathbf{1 a}$ и $\mathbf{1 b}$ образовывались продукты 4a (96 \%) и 4b (97\%), соответственно [4].

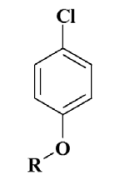

1a $\mathbf{R}=\mathbf{H}$

1b $\mathrm{R}=\mathrm{CH}_{3}$

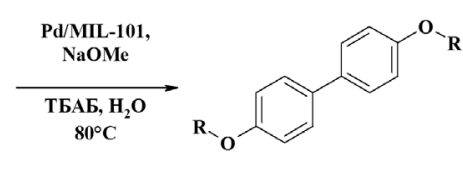

4a $R=H$ 4b $\mathrm{R}=\mathrm{CH}_{3}$
Независимо от предыдущей группы, взаимодействие производных $n$-хлорфенола и фенилбороновой кислоты было изучено под руководством P. L. Diaconescu [5]. В качестве катализатора использовались наночастицы палладия, интерес к которым возрастает из-за преимуществ, предлагаемых этими «полугетерогенными катализаторами». Эти преимущества сочетают в себе характеристики гетерогенного катализа (восстановление и рецирку- лируемость) и гомогенного катализа (относительно низкая каталитическая нагрузка и хорошая селективность). Кроме того, из-за их большой площади поверхности, металлические наночастицы обычно имеют высокую реакционную способность в мягких условиях.
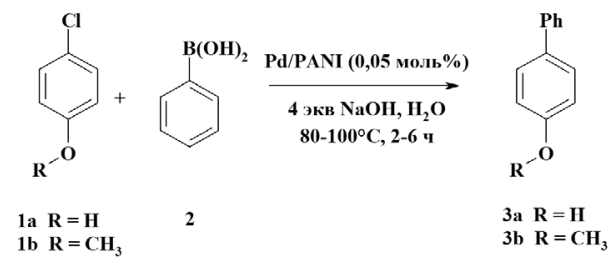

Наночастицы палладия получают путем добавления соли палладия (II) к водной дисперсии полианилина (ПАНИ). Высокая площадь поверхности и пористость ПАНИ-нановолокон служат идеальной средой, чтобы сделать нанокомпозиты металл/полианилин. Для того чтобы воспользоваться этими характеристиками, были задействованы ПАНИ-нановолокна в качестве носителя наночастиц палладия. В результате использования такого катализатора образуются продукты 3а (88 \%) и $\mathbf{3 b}(92 \%)$ [6].

Свой способ синтеза $n$-фенилфенолов был предложен Н. А. Бумагиным и В. В. Быковым [7]. Ими было описано получение большого числа биарильных соединений, получаемых в том числе, и из хлорфенолов 1a с 92 \% выходом.

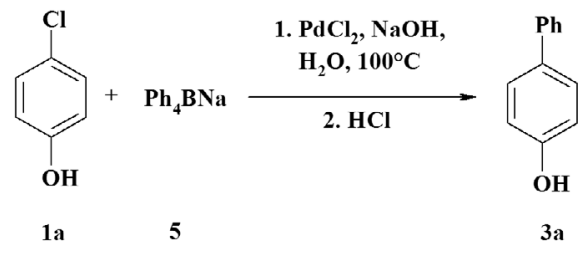

Использовалось 3 моль палладиевого катализатора, 4 ммоль\% основа- 
ния и 1 ммоль бората 4. Реакцию проводилась в течение трех часов.

Данный метод не уступает по эффективности как предшествующим, так и нижеизложенным методам.

Привлекательным выглядит синтез, включающий в себя использование простой и легко доступной каталитической системы кобальта и титана, который проходит в мягких условиях, а также обладает высокой избирательностью и региоселективностью. X. F. Duan и его сотрудниками был представлен комплекс кобальт/титан, который катализирует реакции кросссочетания между арилпроизводными магния и арилхлоридами [8]. Эта реакция легко протекает в присутствии 40 моль \% $\mathrm{Ti}(\mathrm{OEt})_{4}$ и 7,5 моль\% $\mathrm{CoCl}_{2}$, 15 моль \% $\mathrm{PBu}_{3}$.

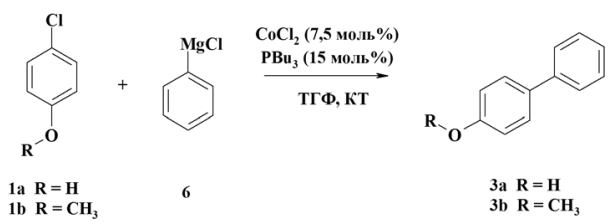

Соединения $\mathbf{3 a}$ и $\mathbf{3 b}$ образуются с выходом 56 и 86 \% соответственно.

Реакции с участием металлоорганических реагентов являются весьма эффективным и практичным способом для образования связей С-С. С магнийорганикой работала и другая группа исследователей [9]. При использовании тех же исходных веществ 1a и $\mathbf{1 b}$ и реагентов $\mathrm{Pd}_{2}(\mathrm{dba})_{3}(1$ моль \%), IPrHCl (4 моль \%), а также фенилмагнийбромида 6 (было использовано 2,5 и 1 эквивалента, соответственно) в тетрагидрофуране, при температуре $80^{\circ} \mathrm{C}$ образуются продукты 3a и $3 \mathbf{b}$ с соответствующими выходами в 95 и $97 \%$.

Над получением биарильных производных работал также M.-J. Jin c коллегами [10]. Ими был использован в качестве катализатора комплекс палладия и дикетоиминофосфина. Результаты показывают, что эта каталитическая система позволяет использовать менее реакционноспособные субстраты, такие как неактивные или стерически затрудненные арилхлориды. Загрузки катализатора, равной 0,5 моль \%, было достаточно для достижения высокой эффективности при относительно мягких условиях реакции.

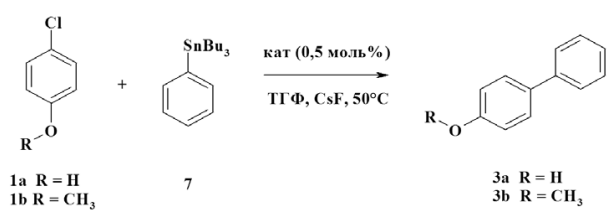

При проведении данных реакций в течение 4 и 5 ч образовывались соответственно продукты 3a и $3 \mathbf{b}$ с выходом $89 \%$.

Группой исследователей под руководством A. Albini было предложено замещать атом хлора на дурол 8 с 60 \% выходом продукта реакции 9 [11].

Фотоарилирование проводили с использованием 0,2 моль дурола 8 и 0,02 моль 4-хлорфенола 1а в 30 мл растворителя в течение 7 ч.<smiles>Oc1ccc(Cl)cc1</smiles>

1a

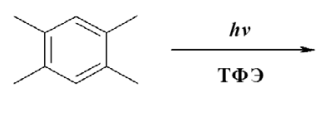

8<smiles>Cc1cc(C)c(C)c(-c2ccc(O)cc2)c1C</smiles>

9
Однако данный способ уступает ранее описанным методам получения.

Таким образом, синтез биарильных соединений - это достаточно популярные реакции кросс-сочетания хлорфенолов с участием различных систем катализаторов. Наиболее выгодно использовать для получения биарилов реакции с участием бороновой кисло- 
ты и наночастиц палладия, а также реакции с оловоорганикой.

\section{Введение других функциональ- ных групп}

Следующим направлением модификаций являются арилнитрилы, которые входят в структуру целого ряда красителей, гербицидов, натуральных продуктов и фармацевтических препаратов. Также они являются полезными промежуточными продуктами синтеза [12-13]. Реакции по получению ароматических нитрилов были проведены N. E. Leadbeater с коллегой [14]. Процесс осуществлялся в микроволновом реакторе, с установленными значениями мощности 120 Вт и порогового значения давления 200 фунтов на квадратный дюйм.
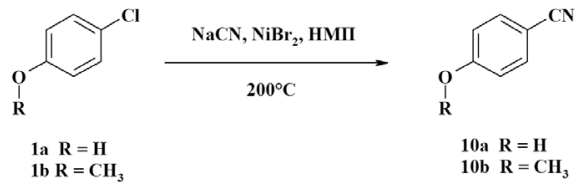

В экспериментах использовали 1 ммоль арилхлорида, 2 ммоль цианида натрия, 1 ммоль бромида никеля в 1 мл N-метил-2-пирролидона (НМП). В результате через 20 и 10 мин. образуются соответственно продукты 10а (99 $\%)$ и $\mathbf{1 0 b}(61 \%)$.

Таким образом, реакцию выгодно использовать для создания $n$-цианофенолов, так как с 4-хлорфенолом синтез протекает селективно и с высоким выходом.

Реакции производных 4-хлорфенолов с альдегидами позволяют легко получить алкиларилкетоны с хорошими выходами. Они широко используются в фармацевтической и парфюмерной промышленности, промышленности красителей и агрохимии. Такие соединения, как правило, синтезируют с по- мощью традиционных реакций по механизму Фриделя - Крафтса. Реакции включают в себя работу с опасными реагентами и не идут с использованием аренов, содержащих электроноакцепторные заместители [15-17].

Группой исследователей под руководством J. Хіао был предложен свой более доступный метод синтеза [18]. Ими были проведены реакции в присутствии палладиевых катализаторов с использованием различных лигандов, которые показали высокую активность по отношению к хлорфенолам и хлоранизолам. Было показано, что использование лиганда L1 дает самые высокие выходы.

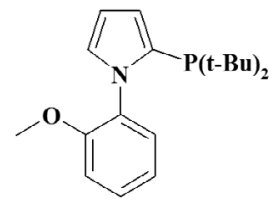

L1

Также положительно влияет на селективность и выход реакции использование диметиламина в качестве растворителя, наличие молекулярных сит $4 \AA ̊$ и пирролидина в реакционной смеси при нагревании до $140{ }^{\circ} \mathrm{C}$.

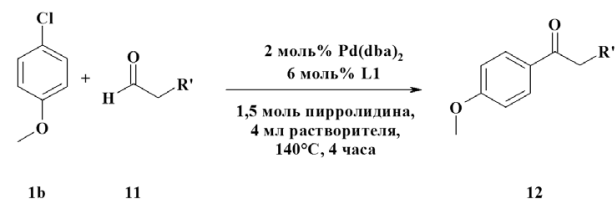

В результате был получен большой ряд соединений 12, с различными заместителями R', природа которых не влияет на протекание реакции, с выходами в 40-78 \%.

Таким образом, данные реакции представляют значительный интерес для модификации хлоркаликсаренов.

а-Арилкарбонильные производные являются важными структурными со- 
единениями во многих натуральных продуктах и фармацевтически активных веществах. Хотя арилирование простых монокарбонильных соединений представляет собой хорошо известную методику, металл-катализируемое арилирование $\beta$-дикарбонильных производных является более сложной задачей. Стерически требовательный лиганд - ди-трет-бутилнеопентилфосфин (ДТБНпП) - в комбинации с $\mathrm{Pd}(\mathrm{dba})_{2}$ является эффективным катализатором для сочетания арилхлоридов с диэтилмалонатом 13. В результате экспериментов были получены соединения 14a (85\%) и $\mathbf{1 4 b}$ (83\%) [19].
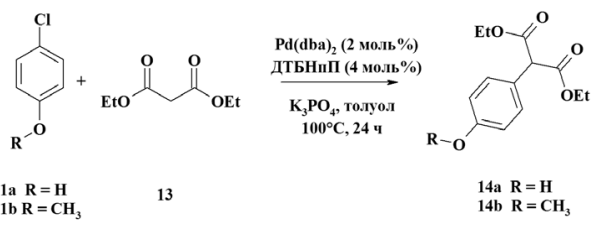

Реакция кросс-сочетания по механизму Соногаширы между арилгалогенидом и терминальным алкином стала одной из наиболее широко используемых реакций, которые применяют для образования углерод-углеродной связи в органической химии [20-24].

Реакция была предложена в качестве эффективной методики для синтеза дендримеров, конъюгированных олигомеров и полимеров, замещенных алкинов. Также они являются интермедиатами при синтезе натуральных продуктов, фармацевтических препаратов, оптических материалов и т. д.

Группой исследователей под руководством S. Pal были исследованы реакции кросс-сочетания фенилацетилена и различных арилгалогенидов с использованием в качестве катализатора созданного ими комплекса с палладием L2 [25].

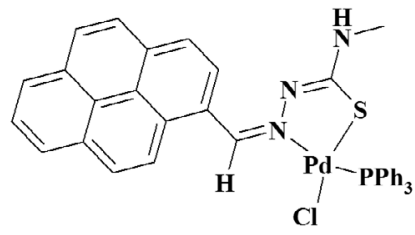

L2

Реакции проводились в ДМФА в присутствии триэтиламина при комнатной температуре в течение 24 ч. Результатами исследований стали соединения 15a (50 \%) и 15b (54\%).

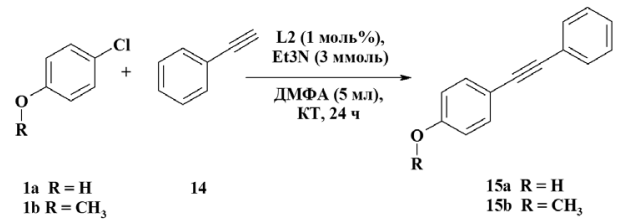

Арилгалогениды использовались также для образования индазолов. Индазолы редко встречаются в природе, но они являются важным классом гетероциклов в фармацевтической и агрохимической отраслях. Кроме того, синтез 3-арил-1Н-индазолов путем перекрестного сочетания $1 \mathrm{H}$-индазолов, имеющих метиловый заместитель в 3-м положении, и арилгалогенидов является привлекательным, так как он позволяет использовать полученное соединение в дальнейших модификациях.

Получением такого ряда соединений занимались В. А. Egan и Р. М. Burton [26]. Исходными веществами были производные арилгалогенидов (1 экв) и полученный этими же исследователями борированный индазол (1,3 экв). В качестве катализатора использовали комплекс с палладием L3.
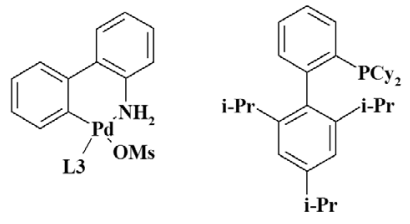

L3 
Эти реакции могут проходить как при $55{ }^{\circ} \mathrm{C}$ в течение 16 ч (условия А), так и в условиях микроволнового излучения $\left(100{ }^{\circ} \mathrm{C}\right.$ в течение 20 мин. (условия Б)). В качестве растворителя использовали смесь трет-бутилметилового эфира (ТБМЭ) и воды в соотношении 10:1.
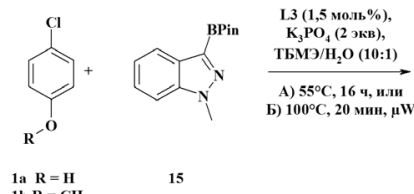

1a $\mathrm{R}=\mathrm{H}$
1b $\mathrm{R}=\mathrm{CH}_{3}$

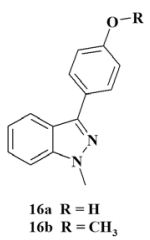

В результате были синтезированы соединения 16a и 16b с выходом в 84 и $76 \%$, соответственно.
Кроме того, в тех же условиях были исследованы реакции с другими производными индазола и получены соответствующие продукты. Результаты представлены в табл. 1 .

Таким образом, вышеизложенные синтезы играют важную роль и позволяют предполагать создание подобного ряда соединений с $n$-хлоркаликсаренами.

Фрагмент $\gamma$-лактона присутствует во многих биологически активных природных соединениях. В частности, некоторые бензил- и арилзамещенные $\gamma$-лактоны проявляют противораковую активность или используются в качестве промежуточных продуктов

Таблица 1

Борирование производных индазола и последующее арилирование

\begin{tabular}{c|c|c|c|}
\hline Исходное соединение & Продукт реакции & Выход, \% \\
\hline & & \\
\hline
\end{tabular}


для синтеза антибиотических противоопухолевых агентов [27-29].

Группа исследователей под руководством A. Albini занималась фотохимическим синтезом производных арилхлоридов и кислот К1, К2 и К3.

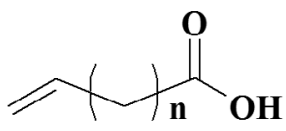

$$
\begin{aligned}
& K 1, n=1 \\
& K 2, n=2 \\
& K 3, n=3
\end{aligned}
$$

Поскольку фотолизу благоприятствует использование полярных (протонных) растворителей, облучение

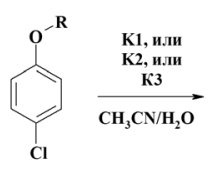

$$
\text { 1a } \mathbf{R}=\mathbf{H}
$$

1a $\mathrm{R}=\mathrm{H}$
1b $\mathrm{R}=\mathrm{CH}_{3}$ 1c $\mathrm{R}=\mathrm{C}_{4} \mathrm{H}_{9}$

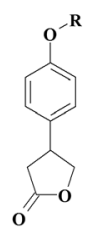

23a $\mathbf{R}=\mathbf{H}$ 23b $\mathbf{R}=\mathrm{CH}_{3}$ $23 \mathrm{c} \quad \mathrm{R}=\mathrm{C}_{4} \mathrm{H}_{9}$

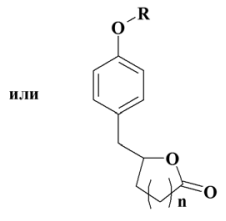

24a $R=H, n=2$ 24b $\mathrm{R}=\mathrm{CH}_{3}, \mathrm{n}=\mathbf{2}$ 24c $\mathrm{R}=\mathrm{C}_{4} \mathrm{H}_{9}, \mathrm{n}=\mathbf{2}$ $25 \mathrm{R}=\mathrm{C}_{4} \mathrm{H}_{9}, \mathrm{n}=3$
(310 нм, 254 нм, для $n$-бутоксихлорбензола) проводили в системе ацетонитрил-вода в соотношении 5:1.

Результаты реакций представлены в табл. 2.

Также были исследованы реакции хлорфенола с другими ненасыщенными кислотами. Результаты реакций представлены в табл. 3 [30].

Все это позволяет указать на значимость изложенных реакций и использовать их для модификации хлоркаликсаренов.

Кросс-сочетание с образованием С-С связи - обширная область применения хлорпроизводных фенола. Продукты синтеза применяют во многих отраслях, вплоть до биологически активных веществ. Модифицированные каликсарены могут комбинировать свойства соединений, тем самым увеличив свою область применения.

\section{Реакции с образованием C-N связи}

Реакции кросс-сочетания хлораренов включают в себя не только образование С-С связи, но и не менее важное образование C-N связи. Причем азотсодержащие органические соединения не только обладают разнообразной биологической активностью, но и служат в качестве строительного блока для различных макромолекул и новых материалов [31-34].

Группа индийских исследователей изучала такого рода реакции с уча-
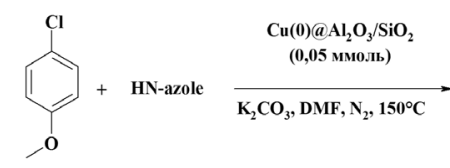
1a $\mathrm{R}=\mathrm{H}$
1b $\mathrm{R}=\mathrm{CH}_{3}$ 28-30 стием катализатора на основе меди. Реакции проводили с использованием 1 ммоль арена, 1,1 ммоль амина, 1,5 ммоль основания в 2 мл растворителя под атмосферой азота [36].

Результаты реакций указаны в табл. 4 [35].

Таблица 2

Фотоиндуцированный синтез лактонов

\begin{tabular}{c|c|c|c} 
Заместитель $\mathbf{R}$ & Время, ч & Продукт & Выход, $\%$ \\
\hline $\mathrm{H}$ & 14 & $\mathbf{2 3 a - c}$ & 52 \\
\hline $\mathrm{H}$ & 14 & $\mathbf{2 4 a}$ & 95 \\
\hline $\mathrm{CH}_{3}$ & 14 & $\mathbf{2 4 b}$ & 72 \\
\hline $\mathrm{C}_{4} \mathrm{H}_{9}$ & 8 & $\mathbf{2 4 c}$ & 57 \\
\hline $\mathrm{C}_{4} \mathrm{H}_{9}$ & 14 & $\mathbf{2 5}$ & 57
\end{tabular}


Таблица 3

Фотоиндуцированный синтез лактонов из хлорфенола

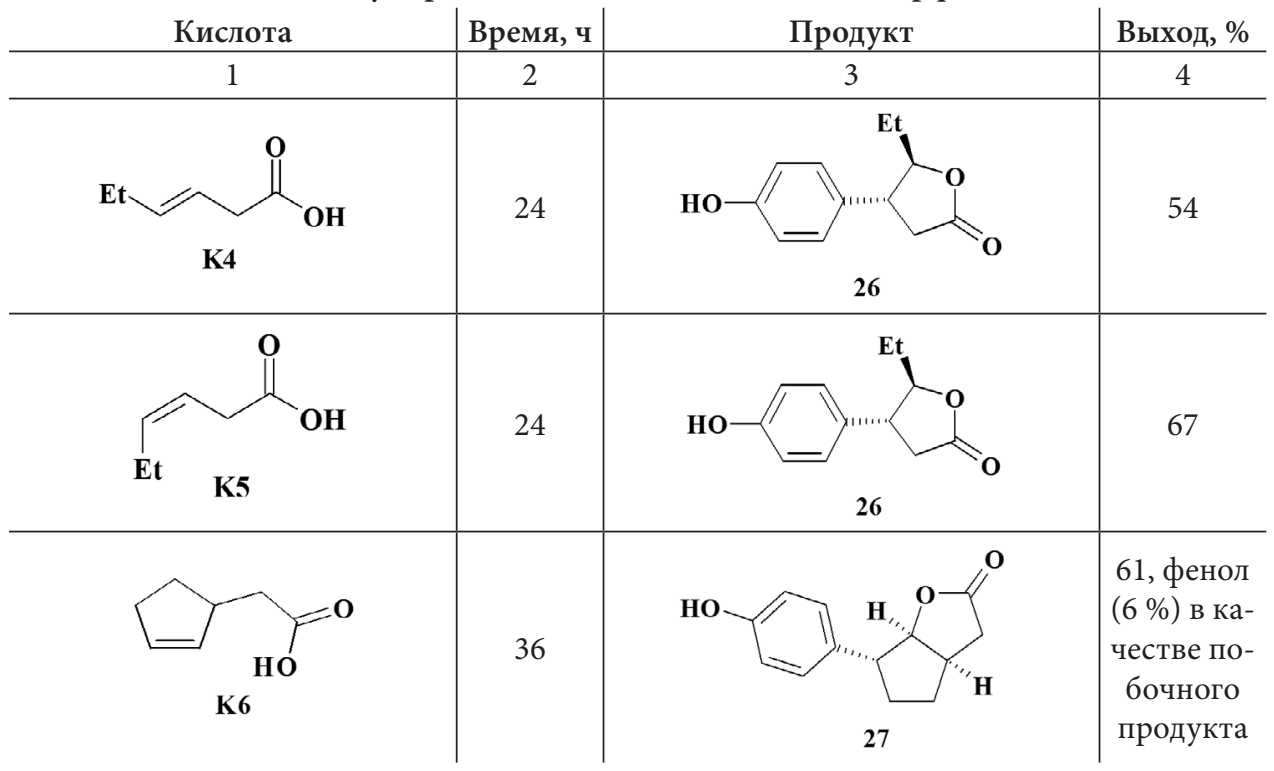

Таблица 4

$\mathrm{N}$-арилирование гетероциклических аминов арилхлоридами

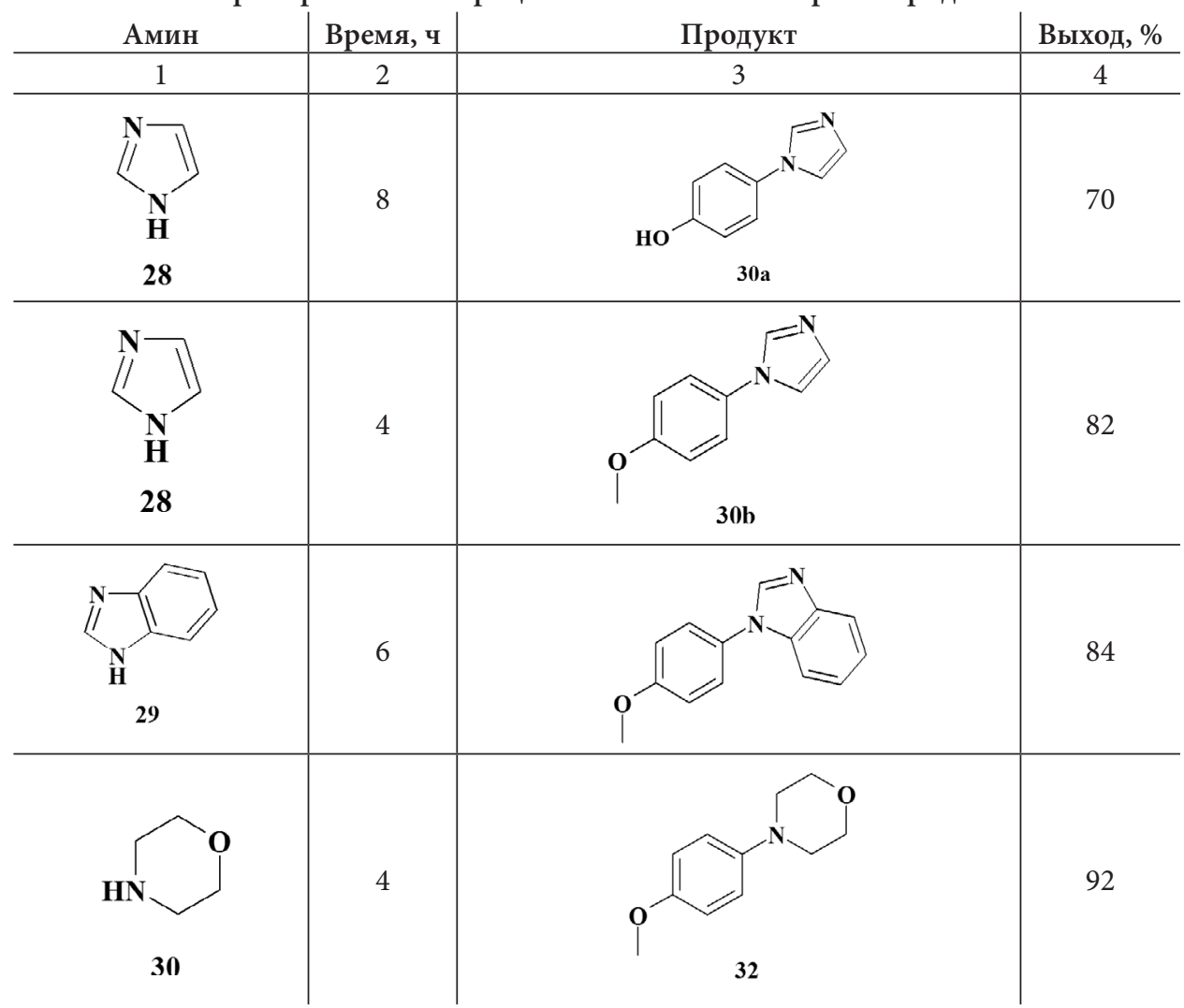


Замещением хлора в арилхлоридах на азотсодержащие соединения также занимались американские исследователи, однако вместо медного катализатора они использовали палладиевый комплекс с лигандом L4.<smiles>CCCCC(C)c1ccccc1-c1c(C(C)C)cc(C(C)C)cc1C(C)C</smiles>

L4

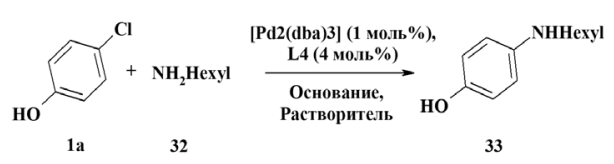

Было исследовано влияние растворителя, основания и температуры и получены следующие результаты (табл. 5).

Было отмечено, что лучшими для получения соединения 33 являются условия под номером 3 с использованием LiN(TMS) ${ }_{2}$ в толуоле при температуре $50{ }^{\circ} \mathrm{C}$ в течение 2 ч. Выход целевого продукта составил $94 \%$.

Также были проведены реакции с участием аминогетероцикла 34. Одним из ряда полученных соединений стал продукт 35 с 92 \% выходом.

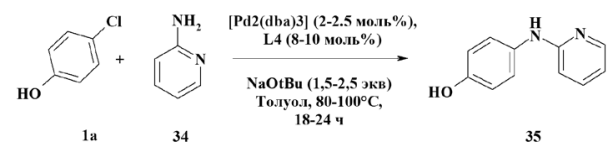

Эти реакции являются важной составляющей ряда кросс-сочетаний с образованием C-N связи.

Следующая группа американских исследователей также использовала палладиевый катализатор. В качестве лиганда было использовано соединение L5 [37].

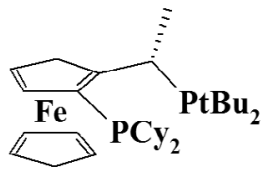

L5

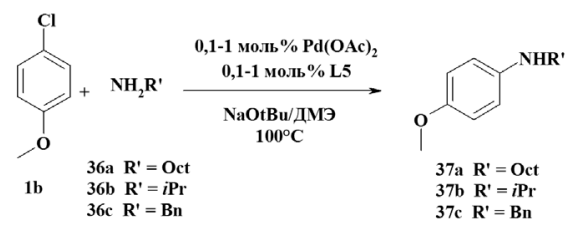

Результаты реакции приведены в табл. 6.

Реакции проводили при соотношении 1:1 ацетата палладия к лиганду L5. Использовали 1,0 ммоль хлоранизола $\mathbf{1 b}, 1,2$ экв амина и 1,4 экв $\mathrm{NaO} t \mathrm{Bu}$ в 1 мл ДМЭ. В случае с участием октиламина 36а требуется 3,0 экв азотсодержащего вещества. Все реакции идут с хорошими выходами.

Также были изучены реакции с хлорфенолом 1а и получены соответствующие фениламины 39a-b.

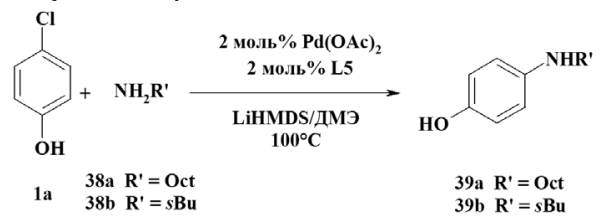

Результаты исследований занесены в табл. 7.

Реакции также проводили при соотношении 1:1 ацетата палладия к лиганду L5. Использовались 1,0 ммоль хлорфенола 1a, 1,2 экв амина и 2,4 экв LiHMDS в 1 мл ДМЭ.

Таким образом, реакции с использованием хлоранизола имеют более хорошие выходы, по сравнению с анилированием хлорфенола, и требуют меньшего расхода реагентов.

Кроме аминирования хлорфенолов и анизолов, существуют также реакции амидирования. Изучением этих 
$\mathrm{N}$-арилирование хлорфенолом

\begin{tabular}{c|c|c|c|c|c} 
№ & Основание & Растворитель & Температура, ${ }^{\circ} \mathrm{C}$ & Время, ч & Выход, $\%$ \\
\hline 1 & $\mathrm{LiN}(\mathrm{TMS})_{2}$ & ТГФ & КТ & 46 & 94 \\
\hline 2 & $\mathrm{LiN}(\mathrm{TMS})_{2}$ & ТГФ & 40 & 24 & 94 \\
\hline 3 & $\mathrm{LiN}(\mathrm{TMS})_{2}$ & Толуол & 50 & 2 & 94 \\
\hline 4 & $\mathrm{NaO} t \mathrm{Bu}$ & Толуол & 100 & 24 & 89
\end{tabular}

Таблица 6

$\mathrm{N}$-арилирование хлоранизолом

\begin{tabular}{c|c|c|c|c|c|c} 
№ & Реагент & $\begin{array}{c}\text { Катализатор, } \\
\text { моль\% }\end{array}$ & Температура, ${ }^{\circ} \mathrm{C}$ & Время, ч & Продукт & Выход, \% \\
\hline 1 & 36a & 0,1 & 100 & 48 & $37 \mathbf{a}$ & 92 \\
\hline 2 & $36 \mathbf{b}$ & 1,0 & 100 & $18-24$ & $37 \mathrm{~b}$ & 94 \\
\hline 3 & $36 \mathrm{c}$ & 0,1 & 100 & 48 & $37 \mathrm{c}$ & 90
\end{tabular}

реакций занималась группа исследователей под руководством S. L. Buchwald [38]. Сначала было изучено влияние различных условий на амидирование хлоранизолов 1 b с бензамидом 40 c участием палладиевого катализатора и лиганда L4.

Реакцию проводили с использованием 1,2 экв. амида 40, 0,5 моль\% катализатора, 2,5 моль\% лиганда в 0,5 моль растворителя:<smiles>COc1ccc(Cl)cc1</smiles>

$1 \mathbf{b}$

Результаты исследований представлены в табл. 8.

Было отмечено, что самые высокие выходы образуются в условиях 1 и 5 , а выгоднее использовать фосфат калия и трет-бутиловый спирт.

Затем в выбранных условиях был получен ряд соединений (табл. 9).

Использовали 1,0-1,5 экв. амида, 1,2-1,5 экв. основания, 0,5 моль рас-

Таблица 7 Аминирование хлорфенола

\begin{tabular}{|c|c|c|c|c|}
\hline$\stackrel{21}{2}$ & 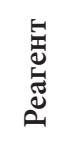 & مै & 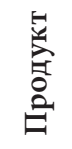 & 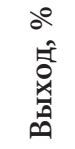 \\
\hline 1 & $38 \mathrm{a}$ & 18 & $39 a$ & 72 \\
\hline 2 & $38 b$ & 20 & $39 b$ & 66 \\
\hline
\end{tabular}

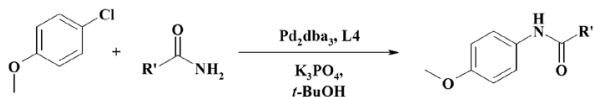

Ib 42a-d 43a-d

творителя и соотношение кат/лиганд равно 1/2,5.

Наблюдались высокие выходы продукта реакции с малыми затратами реагентов, за исключением реакции с использованием карбоксамида.

Таким образом, замещение хлора с образованием связи C-N играет не менее важную роль в модифицировании хлораренов, как и кросс-сочетания с образованием С-С связи.

\section{Реакции с образованием C-S связи}

Арилсульфиды являются ценными промежуточными продуктами в органическом синтезе биологически и фармацевтически активных молекул, органических материалов или промежуточных продуктов в производст- 
Таблица 8

Амидирование бензамидом

\begin{tabular}{c|c|c|c} 
№ & Основание & Растворитель & Выход, \% \\
\hline 1 & $\mathrm{~K}_{3} \mathrm{PO}_{4}$ & $t$-ВuОН & 94 \\
\hline 2 & $\mathrm{~K}_{3} \mathrm{PO}_{4}$ & Толуол & 89 \\
\hline 3 & $\mathrm{~K}_{3} \mathrm{PO}_{4}$ & $1,4-$ диоксан & 79 \\
\hline 4 & $\mathrm{~K}_{3} \mathrm{CO}_{3}$ & $t$-ВuOH & 45 \\
\hline 5 & $\mathrm{Cs}_{2} \mathrm{CO}_{3}$ & $t$-BuOH & 97 \\
\hline 6 & $t$-BuONa & $t$-ВuОН & 28 \\
\hline 7 & LHMDS & Толуол & 1
\end{tabular}

Таблица 9

Амидирование хлоранизола

\begin{tabular}{c|c|c|c|c|c} 
№ & Реагент & R' & Рd (моль\%) & Продукт & Выход, \% \\
\hline 1 & 42a & Ме & 1 & 43a & 99 \\
\hline 2 & 42b & Су & 1 & 43b & 96 \\
\hline 3 & 42c & Н & 4 & $43 \mathrm{c}$ & 82 \\
\hline 4 & 42d & о-фенил & 2 & $43 \mathrm{~d}$ & 92
\end{tabular}

ве этих молекул. Ряд арилсульфидов показал потенциальное клиническое применение, например для лечения болезни Альцгеймера и заболевания Паркинсона, для лечения астмы и обструктивных заболеваний легких, для лечения вируса иммунодефицита человека (ВИЧ) [39-44].

Группа американских исследователей под руководством J. F. Hartwig занималась изучением взаимодействия хлораренов и тиолпроизводных [45-46].
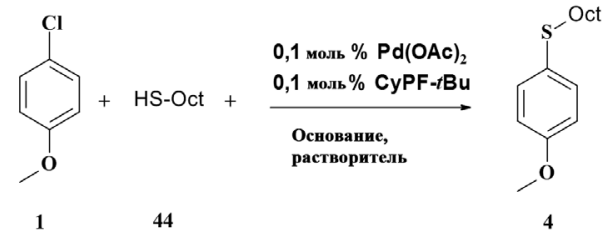

Результаты отмечены в табл. 10.

Bce эксперименты проводились с соотношением 1:1 металла к лиганду, с 1 ммоль обоих 4-хлоранизола $\mathbf{1 b}$ и 1-октантиола 44 и 1,1 экв основания в 1,5 мл растворителя. В качестве лиганда было выбрано соединение L5. При проведении реакции в условиях под номером 7 использовали 0,05 \%-ную загрузку катализатора. В условиях 8 $\left[\mathrm{Pd}(\mathrm{dba})_{2}\right]$ использовали в качестве предшественника ацетата палладия.

Было отмечено, что условия под номером 4 являются наиболее выгодными.

Также был проведен ряд реакций с 4-хлоранизолом и тиофенолом.

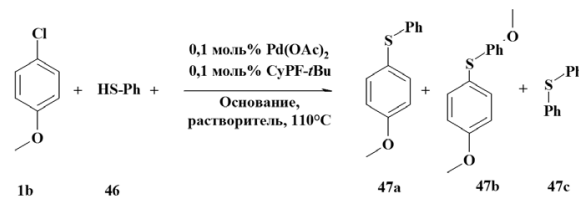

В выбранных ранее условиях реакция шла неселективно, с образованием побочных продуктов 47b и $47 \mathrm{c}$. $\mathrm{B}$ результате оптимизаций удалось подобрать такие условия, чтобы образовывался только целевой продукт (табл. 11).

Bce эксперименты проводились с соотношением 1:1 катализатора к лиганду, с 1 ммоль обоих исходных веществ $1 \mathrm{~b}$ и 46, 1,1 экв основания при $110{ }^{\circ} \mathrm{C}$ в 1,5 мл растворителя. Было 
Таблица 10

Взаимодействие хлоранизола и 1-октантиола

\begin{tabular}{|c|c|c|c|c|c|}
\hline № & Основание & Растворитель & Температура, ${ }^{\circ} \mathrm{C}$ & Время, ч & Выход, \% \\
\hline 1 & $\mathrm{NaO} t \mathrm{Bu}$ & ДМЭ & 100 & 18 & 84 \\
\hline 2 & $\mathrm{KO} t \mathrm{Bu}$ & ДМЭ & 100 & 18 & 80 \\
\hline 3 & NaHMDS & ДМЭ & 100 & 18 & 57 \\
\hline 4 & $\mathrm{NaOtBu}$ & ДМЭ & 110 & $<4$ & 98 \\
\hline 5 & $\mathrm{KO} t \mathrm{Bu}$ & ДМЭ & 110 & 18 & 87 \\
\hline 6 & $\mathrm{NaOtBu}$ & 1,4-диоксан & 110 & 5 & 94 \\
\hline 7 & $\mathrm{NaOtBu}$ & ДМЭ & 110 & 48 & 85 \\
\hline 8 & $\mathrm{NaOtBu}$ & ДМЭ & 110 & 7 & 96 \\
\hline
\end{tabular}

Взаимодействие хлоранизола и тиофенола

Таблица 11

\begin{tabular}{c|c|c|c|c|c|c} 
№ & Основание & Растворитель & Катализатор & Загрузка, \% & Время, ч & $\begin{array}{c}\text { 47:47b:47c, } \\
\%\end{array}$ \\
\hline 1 & $\mathrm{NaO} t \mathrm{Bu}$ & ДМЭ & $\mathrm{Pd}(\mathrm{OAc})_{2}$ & 0,5 & 12 & $91: 4: 5$ \\
\hline 2 & $\mathrm{KO} t \mathrm{Bu}$ & ДМЭ & $\mathrm{Pd}(\mathrm{OAc})_{2}$ & 0,5 & 12 & $98: 1: 1$ \\
\hline 3 & $\mathrm{NaHMDS}$ & ДМЭ & $\mathrm{Pd}(\mathrm{OAc})_{2}$ & 0,5 & 12 & $71: 15: 14$ \\
\hline 4 & $\mathrm{LiHMDS}$ & ДМЭ & $\mathrm{Pd}(\mathrm{OAc})_{2}$ & 0,5 & 12 & $56: 24: 20$ \\
\hline 5 & $\mathrm{NaOtBu}$ & 1,4 -диоксан & $\mathrm{Pd}(\mathrm{OAc})_{2}$ & 0,5 & 12 & $96: 2: 2$ \\
\hline 6 & $\mathrm{KO} t \mathrm{Bu}$ & 1,4 -диоксан & $\mathrm{Pd}(\mathrm{OAc})_{2}$ & 0,5 & 12 & $97: 2: 1$ \\
\hline 7 & $\mathrm{NaOtBu}$ & Толуол & $\mathrm{Pd}(\mathrm{OAc})_{2}$ & 0,5 & 12 & $98: 1: 1$ \\
\hline 8 & $\mathrm{KO} t \mathrm{Bu}$ & Толуол & $\mathrm{Pd}(\mathrm{OAc})_{2}$ & 0,5 & 12 & $>98: 1:<1$ \\
\hline 9 & $\mathrm{KO} t \mathrm{Bu}$ & Толуол & $\mathrm{Pd}(\mathrm{OAc})_{2}$ & 1,0 & 6 & $>98:<1:<1$ \\
\hline 10 & $\mathrm{KO} t \mathrm{Bu}$ & Толуол & {$\left[\mathrm{Pd}(\mathrm{dba})_{2}\right]$} & 0,5 & 12 & $>99,5: 0,5:-$ \\
\hline 11 & $\mathrm{KO} t \mathrm{Bu}$ & Толуол & {$\left[\mathrm{Pd}(\mathrm{dba})_{2}\right]$} & 1,0 & $<4$ & $>99,5: 0,5:-$
\end{tabular}

отмечено, что выгоднее использовать условия под номером 11.

Далее в этих условиях были проведены следующие реакции и получены соответствующие продукты (табл. 12).
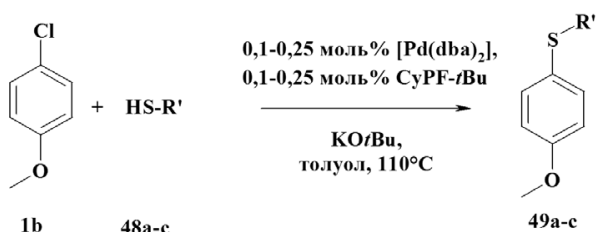

Bce эксперименты проводились с соотношением 1:1 катализатора к лиганду, с 1 ммоль обоих исходных веществ $\mathbf{1 b}$ и $\mathbf{4 8 a - c}$ в толуоле (1,5 мл) в течение 2-24 ч при $110{ }^{\circ} \mathrm{C}$.
С 4-хлорфенолом также были проведены реакции и получены соответствующие продукты (табл. 13).

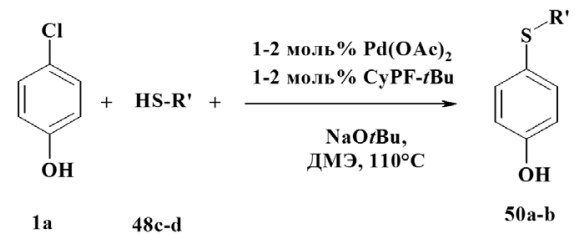

Bсе эксперименты проводились с соотношением 1:1 катализатора к лиганду, с 1 ммоль обоих исходных веществ в DME (1,5 мл) в течение 2-5 ч нагревания при $110^{\circ} \mathrm{C}$ [45-46].

Таким образом, кросс-сочетания с образованием C-S связи являются важными реакциями замещения атома хлора. 
Таблица 12

Тиоарилирование 4-хлоранизола

\begin{tabular}{|c|c|c|c|c|}
\hline $\begin{array}{c}\text { Катализатор, } \\
\text { моль\% } \\
\end{array}$ & Реагент & $\mathrm{R}^{\prime}$ & Продукт & Выход, \% \\
\hline 0,1 & $48 a$ & & $49 a$ & 98 \\
\hline 0,25 & $48 \mathrm{~b}$ & & $49 b$ & 99 \\
\hline 0,25 & $48 \mathrm{c}$ & & $49 c$ & 94 \\
\hline
\end{tabular}

Тиоарилирование 4-хлорфенола

\begin{tabular}{c|c|c|c|c}
$\begin{array}{c}\text { Катализатор, } \\
\text { моль\% }\end{array}$ & Реагент & R' & Продукт & Выход, \% \\
\hline 2,0 & $48 \mathrm{c}$ & \\
\hline \multirow{2}{*}{1,0} & $48 \mathrm{~d}$ & $*$ & $50 \mathrm{a}$ & 91 \\
\hline
\end{tabular}

\section{Реакции с образованием С-В связи}

Арилбороновые кислоты представляют собой универсальные реагенты для органического синтеза, которые используются в образовании С-O, C-N и С-С связей [47]. Кроме того, использование органоборанов особенно привлекательно из-за их высокой стабильности и низкой токсичности.

S. L. Buchwald и его группой были проведены исследования в этой области [48]. Они проводили кросс-сочетания 4-хлорфенола 1а и 4-хлоранизола $\mathbf{1 b}$ и бис(пинаколато)диборона 51.

Соотношение катализатора и лиганда составляло 1:2. При использовании 2 моль\% ацетата палладия ре-

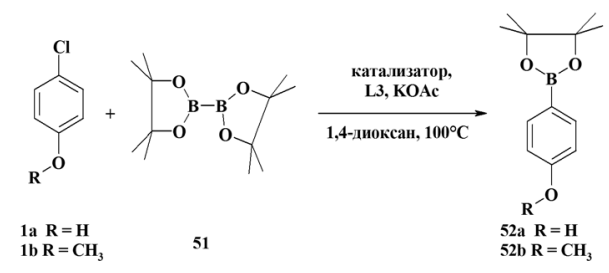

акцию проводили в течение 10 мин. с образованием $97 \%$ продукта 52b. В случае же с участием 0,05 моль \% $\mathrm{Pd}_{2} \mathrm{dba}_{3}$ в течение 24 ч образовался продукт 52b с 94 \% выходом, а при увеличении количества катализатора до 1 моль \% - продукт 52b через 10 мин. с $97 \%$ выходом, а 52а через 30 мин. с $82 \%$-ным выходом. 
Также с хлоранизолом была проведена реакция в присутствии 2,0 моль\% ацетата палладия, лиганда L5 (в соотношении к катализатору 3:1), фосфата калия (3 экв) в 2 мл растворителя и при комнатной температуре. В результате было получено соединение ИИ с выходом $97 \%$.

Таким образом, кросс-сочетания с образованием С-В связи имеют не менее важную роль, чем вышеописанные реакции.

\section{Заключение}

Таким образом, в данном обзоре показан высокий синтетический потенциал $n$-хлорфенолов и $n$-хлоранизолов. Показано, что за счет образования новых связей C-C, C-N, C-S и C-B вместо $\mathrm{C}-\mathrm{Cl}$, производные хлорфенола нашли широкое применение в синте- зе сложных органических соединений. Стоит отметить высокую не только фундаментальную, но и практическую значимость данных реакций ввиду доступности и дешевизны исходных хлорзамещенных производных фенола.

\section{References}

1. McElroy W. T., DeShong P. Synthesis of the CD-ring of the anticancer agent streptonigrin: studies of aryl-aryl coupling methodologies. Tetrahedron. 2006;62(29):69456954. DOI: 10.1016/j.tet.2006.04.074.

2. Torres J. C., Pinto A. C., Garden S. J. Application of a catalytic palladium biaryl synthesis reaction, via C-H functionalization, to the total synthesis of Amaryllidaceae alkaloids. Tetrahedron. 2004;60(44):9889-9900. DOI: 10.1016/j.tet.2004.08.030.

3. Miyaura N., Yanagi T., Suzuki A. The Palladium-Catalyzed Cross-Coupling Reaction Of Phenylboronic Acid With Haloarenes In The Presence Of Bases. Synthetic Communications. 1981;11(7):513-519. DOI: 10.1080/00397918108063618.

4. Yuan B., Pan Y., Li Y., Yin B., Jiang H. Angewante Chemie-International Edition. 2010;49:4054-4058.

5. Astruc D., Lu F., Aranzaes J. R. Nanoparticles as recyclable catalysts: The frontier between homogeneous and heterogeneous catalysis. Angewante Chemie-International Edition. 2005;44(48):7852-7872. DOI: 10.1002/anie.200500766.

6. Gallon B. J., Kojima R. W., Kaner R. B., Diaconescu P. L. Palladium nanoparticles supported on polyaniline nanofibers as a semi-heterogeneous catalyst in water. Angewante Chemie-International Edition. 2007;46(38):7251-7254. DOI: 10.1002/ anie.200701389.

7. Bumagin N. A., Bykov V. V. Ligandless palladium catalyzed reactions of arylboronic acids and sodium tetraphenylborate with aryl halides in aqueous media. Tetrahedron. 1997;53(42):14437-14450. DOI: 10.1016/S0040-4020(97)00936-8.

8. Zeng J., Liu K. M., Duan X. F. Organic Letters. 2013;15(20):5342-5345.

9. Huang J., Nolan S. P. Efficient cross-coupling of aryl chlorides with aryl grignard reagents (Kumada reaction) mediated by a palladium/imidazolium chloride system. J. Am. Chem. Soc. 1999;121(42):9889-9890. DOI: 10.1021/ja991703n.

10. Lee D.-H., Qian Y., Park J.-H., Lee J.-S., Shim S.-E. Jin. Adv. Synth. Catal. 2013;355: $1-8$. 
11. Dichiarante V., Fagnoni M., Albini A. Metal-free synthesis of sterically crowded biphenyls by direct Ar-H substitution in alkyl benzenes. Angewante Chemie-International Edition. 2007;46(34):6495-6498. DOI: 10.1002/anie.200701462.

12. Ellis G. P., Romney-Alexander T. M. Cyanation of aromatic halides. Chemical Reviews. 1987;87(4):779-784.

13. Grushin V. V., Alper H. Transformations of chloroarenes, catalyzed by transitionmetal complexes. Chemical Reviews. 1994;94(4):1047-1062.

14. Arvela R. K., Leadbeater N. E. Rapid, Easy Cyanation of Aryl Bromides and Chlorides Using Nickel Salts in Conjunction with Microwave Promotion. J. Org. Chem. 2003;68(23):9122-9125. DOI: 10.1021/jo0350561.

15. Franck H. G., Stadelhofer J. W. Industrial Aromatic Chemistry; Springer-Verlag: Berlin, 1988.

16. Surburg H., Panten J. Common Fragrance and Flavor Materials, 5th ed.; Wiley-VCH: Weinheim, Germany, 2006.

17. Olah G. A. Friedel-Crafts Chemistry; Wiley: New York, 1973.

18. Colbon P., Ruan J., Purdie M., Xiao J. Direct acylation of aryl chlorides with aldehydes by palladium-pyrrolidine Co-catalysis. Organic Letters. 2010;12(16):36703673. DOI: 10.1021/ol101466g.

19. Semmes J. G., Bevans S. L., Mullins C. H., Shaughnessy K. H. Arylation of diethyl malonate and ethyl cyanoacetate catalyzed by palladium/di-tert-butylneopentylphosphine Tetrahedron Letters. 2015;56(23):3447-3450. DOI: 10.1016/j.tetlet.2015.01.072.

20. Kozaki M., Okada K. Snowflake-Like Dendrimers via Site-Selective Synthesis of Dendrons. Organic Letters. 2004;(4):485-488. DOI: 10.1021/ol036011p.

21. Yatabe T., Suzuki Y., Kawanishi Y. J. Liquid crystalline conjugated oligomers: Synthesis and mesomorphic properties of laterally and terminally alkyl-substituted oligo(1,4- phenyleneethynylene)s. J. Materials Chemistry. 2008;18(37):4468-4477. DOI: 10.1039/b808036d.

22. Dasaradhan C., Kumar Y. S., Prabakaran K., Khan F.-R. N., Jeong E. D., Chung E. H. Efficient and convenient copper-free $\mathrm{Pd}(\mathrm{OAc}) 2 /$ Ruphos-catalyzed Sonogashira coupling in the preparation of corfin analogues. Tetrahedron Letters. 2015;56(6):784788. DOI: 10.1016/j.tetlet.2014.12.059.

23. Aronica L. A., Giannotti L., Giuntini S., Caporusso A. M. Synthesis of 2-Alkylideneisochromans by Cyclocarbonylative Sonogashira Reactions. J. Eur, Org. Chem. 2014;31:6858-6862. DOI: 10.1002/ejoc.201402979

24. Gautam P., Maragani R., Misra R. Tuning the HOMO-LUMO gap of donor-substituted benzothiazoles. Tetrahedron Letters. 2014;55(50):6827-6830. DOI: 10.1016/j. tetlet.2014.10.094.

25. Prabhu R. N., Pal S. Copper-free Sonogashira reactions catalyzed by a palladium(II) complex bearing pyrenealdehyde thiosemicarbazonate under ambient conditions. Tetrahedron Letters. 2015;56(37):5252-5256. DOI: 10.1016/j.tetlet.2015.07.076

26. Egan B. A., Burton P. M. Synthesis of 3-aryl-1H-indazoles via iridium-catalysed C-H borylation and Suzuki-Miyaura coupling. RSC Adv. 2014;4(53):27726-27729. DOI: $10.1039 / \mathrm{c} 4 \mathrm{ra} 04235 \mathrm{~b}$. 
27. Brown H. C., Kulkarni S. V., Racherla U. S. Chiral synthesis via organoboranes. 39. A facile synthesis of $\gamma$-substituted- $\gamma$-butyrolactones in exceptionally high enantiomeric purity. J. Organic Chemistry. 1994;59(2):365-369.

28. Lambert J. D., Rice J. E., Hong J., Hou Z., Yang C. S. Synthesis and biological activity of the tea catechin metabolites, M4 and M6 and their methoxy-derivatives. Bioorganic and. Medicinal Chemistry Letters. 2005;15(4):873-876. DOI: 10.1016/j. bmcl.2004.12.070.

29. Asano M., Inoue M., Katoh T. Model studies towards the total synthesis of GKK1032s, novel antibiotic anti-tumor agents: Enantioselective synthesis of the alkyl aryl ether portion of GKK1032s. Synlett. 2005;17:2599-2602. DOI: 10.1055/s-2005-917112.

30. Protti S., Fagnoni M., Albini A. Benzyl (phenyl) $\gamma$ - and $\delta$-lactones via photoinduced tandem Ar-C, C-O bond formation. J. Am. Chem. Soc. 2006;128(33):10670-10671. DOI: $10.1021 /$ ja0627287.

31. Cragg G. M., Grothaus P. G., Newman D. J. Impact of natural products on developing new anti-cancer agents. Chemical Reviews. 2009;109(7):3012-3043. DOI: $10.1021 /$ cr900019.

32. Singh I. P., Bodiwala H. S. Recent advances in anti-HIV natural products. Natural Product Reports. 2010;27(12):1781-1800. DOI: 10.1039/c0np00025f.

33. Cavalli A., Bolognesi M. L., Minarini A., Rosini M., Tumiatti V., Recanatini M., Melchiorre C. Multi-target-directed ligands to combat neurodegenerative diseases. J. Medicinal Chemistry. 2008;51(3):347-370.

34. Bariwal J., Eycken E. V. C-N bond forming cross-coupling reactions: An overview. Chemical Society Reviews. 2013;42(24):9283-9303. DOI: 10.1039/c3cs60228a.

35. Reddy L., Arundhathib R., Rawata D. S. J. Name. 2012;00:1-3.

36. Anderson K. W., Tundel R. E., Ikawa T., Altman R. A., Buchwald S. L. Monodentate phosphines provide highly active catalysts for Pd-catalyzed C-N bond-forming reactions of heteroaromatic halides/amines and $(\mathrm{H}) \mathrm{N}$-heterocycles. Angew. Chem. Int. Ed. 2006;45(39):6523 -6527. DOI: 10.1002/anie.200601612.

37. Shen Q., Shekhar S., Stambuli J. P., Hartwig J. F. Highly reactive, general, and long-lived catalysts for coupling heteroaryl and aryl chlorides with primary nitrogen nucleophiles. Angew. Chem. Int. Ed. 2005;44(9):1371-1375. DOI: 10.1002/ anie. 200462629.

38. Ikawa T., Barder T. E., Biscoe M. R., Buchwald S. L. Pd-catalyzed amidations of aryl chlorides using monodentate biaryl phosphine ligands: A kinetic, computational, and synthetic investigation. J. Am. Chem. Soc. 2007;129(43):13001-13007. DOI: $10.1021 /$ ja0717414.

39. Wang Y., Chackalamannil S., Hu Z., Clader J. W., Greenlee W., Billard W., Binch H., Crosby G., Ruperto V., Duffy R. A., McQuade R., Lachowicz J. E. Design and synthesis of piperidinyl piperidine analogues as potent and selective M2 muscarinic receptor antagonists. Bioorg. Med. Chem. Lett. 2000;10(20):2247-2250. DOI: 10.1016/ S0960-894X(00)00457-1.

40. NielsenS.F., NielsenE.O.,Olsen G. M.,Liljefors T., PetersD. Novelpotentligandsforthe central nicotinic acetylcholine receptor: Synthesis, receptor binding, and 3D-QSAR analysis. J. Med. Chem. 2000;43(11):2217-2226. DOI: 10.1021/jm990973d. 
41. Alcaraz M.-L., Atkinson S., Cornwall P., Foster A. C., Gill D. M., Humphries L. A., Keegan P. S., Kemp R., Merifield E., Nixon R. A., Noble A. J., O’Beirne D., Patel Z. M., Perkins J., Rowan P., Sadler P., Singleton J. T., Tornos J., Watts A. J., Woodland I. A. Efficient syntheses of AZD4407 via thioether formation by nucleophilic attack of organometallic species on sulphur. Organic. Process Research and. Development. 200;9(5):555-569. DOI: 10.1021/op0500483.

42. Kaldor S. W., Kalish V. J., Davies II J. F., Shetty B. V., Fritz J. E., Appelt K., Burgess J. A., Campanale K. M., Chirgadze N. Y., Clawson D. K., Dressman B. A., Hatch S. D., Khalil D. A., Kosa M. B., Lubbehusen P. P., Muesing M. A., Patick A. K., Reich S. H., Su K. S., Tatlock J. H. Viracept (nelfinavir mesylate, AG1343): A potent, orally bioavailable inhibitor of HIV-1 protease. J. Med. Chem. 1997;40(24):3979-3985. DOI: 10.1021/jm9704098.

43. Martino de G., Edler M. C., Regina la G., Coluccia A., Barbera M. C., Barrow D., Nicholson R. I., Chiosis G., Brancale A., Hamel E., Artico M., Silvestri R. New arylthioindoles: Potent inhibitors of tubulin polymerization. 2. Structure-activity relationships and molecular modeling studies. J. Med. Chem. 2006;49(3):947-954. DOI: 10.1021/jm050809s.

44. Martino de G., Regina la G., Coluccia A., Edler M. C., Barbera M. C., Brancale A., Wilcox E., Hamel E., Artico M., Silvestri R. Arylthioindoles, potent inhibitors of tubulin polymerization. J. Med. Chem. 2004;47(25):6120-6123. DOI: 10.1021/ jm049360d.

45. Fernandez-Rodriguez M. A., Shen Q., Hartwig J. F. Highly efficient and functional-group-tolerant catalysts for the palladium-catalyzed coupling of aryl chlorides with thiols. Chemistry - A European. J. 2006;12(30):7782-7796. DOI: 10.1002/ chem.200600949.

46. Fernandez-Rodriguez M. A., Shen Q., Hartwig J. F. A general and long-lived catalyst for the palladium-catalyzed coupling of aryl halides with thiols. J. Am. Chem. Soc. 2006;128(7):2180-2181. DOI: 10.1021/ja0580340.

47. Miyaura N. Top. Curr. Chem. 2002;219:11.

48. Billingsley K. L., Barder T. E., Buchwald S. L. Palladium-catalyzed borylation of aryl chlorides: Scope, applications, and computational studies. Angew. Chem. Int. Ed. 2007;46(28):5359-5363. DOI: 10.1002/anie.200701551.

\section{Cite this article as (как цитировать эту статью):}

Mitin V. V., Ivanova E. A., Prokhorova P. E., Morzherin Yu.Yu. Chlorophenols in organic synthesis. Chimica Techno Acta. 2016;3(3):164-192. DOI: 10.15826/ chimtech.2016.3.3.013. 